\title{
UGOVOR O RADU I ZAKON O OBVEZNIM ODNOSIMA
}

Darko Milković, sudac

Vrhovni sud Republike Hrvatske
UDK: $349.2: 347.4$

Ur: 25. veljače 2016 . Pr.: 16. ožujka 2016.

Stručni rad

\begin{abstract}
Sažetak
$U$ ovom se radi prikazuje $i$ analizira primjena odredbi Zakona o obveznim odnosima u vezi s pitanjima koja se pojavljuju vezano uz ugovor o radu. Obrađuju se svi aspekti ugovora o radu, od sklapanja preko promjene sve do prestanka tog ugovora, s posebnim osvrtom na pitanja koja se rješavaju primjenom odredbi Zakona o obveznim odnosima. Osim toga, primjena tih odredbi relevantna je $i$ kod pojedinih instituta vezanih uz ugovor o radu kao što su stjecanje bez osnove, računanje rokova $i$ odgovornost za štetu nastalu pri ispunjenju obveza iz ugovora o radu. U odnosu na sva pitanja koja se obrađuju, prikazana je i sudska praksa radi uvida pravnih shvaćanja Vrhovnog suda i pojedinih Županijskih sudova, ali isto tako da bi se pokazalo da se odredbe ZOO-a kod rješavanja pojedinih pitanja vezanih uz ugovor o radu, u praksi uvelike primjenjuju.
\end{abstract}

Ključne riječi: ugovor o radu, Zakon o obveznim odnosima, sklapanje ugovora o radu, prestanak ugovora o radu, radno pravo.

\section{1. $U V O D$}

Dvije činjenice uvelike usmjeravaju ugovor o radu prema odredbama Zakona o obveznim odnosima. ${ }^{1}$ Prva je da se radni odnos zasniva ugovorom o radu čime je radni odnos dobio karakteristike ugovornog odnosa čija se pitanja stoga uvelike rješavaju primjenom odredbi ZOO-a. ${ }^{2}$

1 Zakona o obveznim odnosima, Narodne novine, br. 35/05, 41/08, 125/11 i 78/15 u daljnjem tekstu: ZOO

2 Radni je odnos određen kao ugovorni odnos donošenjem prvog Zakona o radu, Narodne novine, broj: 38/95, 54/95, 65/95, 102/98, 17/01, 82/01, 114/03, 123/03, 142/03, 30/04 i $68 / 05$, koji je na snagu stupio 1. siječnja 1996. Do tad je radni odnos bio statusne prirode reguliran odredbama Zakona o osnovnim pravima iz radnog odnosa koji je preuzet Zakonom o preuzimanju saveznih zakona iz oblasti radnih odnosa i zapošljavanja koji se u RH primjenjuju kao republički zakoni, Narodne novine, br. 34/91., i Zakona o radnim odnosima, Narodne novine, br. 25/92, 26/93 i 29/94. 
Druga je činjenica da je čl. 8. st. 4. Zakona o radu ${ }^{3}$ propisano da se na sklapanje, valjanost, prestanak ili drugo pitanje u vezi s ugovorom o radu, kolektivnim ugovorom ili sporazumom sklopljenim između radničkog vijeća i poslodavca, a koje nije uređeno ovim ili drugim zakonom, primjenjuju u skladu s naravi toga ugovora, opći propisi obveznog prava. Dakle, ZR propisuje supsidijarnu primjenu pravila obveznog prava za sva ona pitanja u pogledu ugovora o radu koja nisu uređena nekim od izvora radnog prava. Razmišljanje o supsidijarnom primjeni nailazimo i u ustavnosudskoj praksi koja kaže da ugovor o radu nije ugovor obveznog prava na koji treba prije svega primijeniti odredbe Zakona o obveznim odnosima (Narodne novine, br. 35/05, 41/08 i 125/11 u daljnjem tekstu: ZOO-a). U smislu odredbe čl. 8. st. 4. ZR opći propisi obveznog prava primijenit će se, u skladu s naravi tog ugovora, na sva pitanja u svezi s ugovorom o radu ako ta pitanja nisu uređena ZR-om ili drugim zakonom. ${ }^{4}$

Da bi osigurao što veću primjenu pravila obveznog prava u radnim odnosima, zakonodavac je predvidio da se te odredbe primjenjuju i izvan već spomenute materije o sklapanju, valjanosti i prestanku ugovora o radu. Tako je čl. 111. st. 1. ZR-a propisano ako radnik pretrpi štetu na radu ili u svezi s radom, poslodavac je dužan radniku naknaditi štetu po općim propisima obveznog prava.

Ističemo da primjenu pravila ZOO-a susrećemo i kod kolektivnih ugovora o radu, primjerice kod pitanja stranačke sposobnosti pri sklapanju izmjena i dopuna kolektivnog ugovora. Tu smo prije donošenja Zakona o reprezentativnosti udruga poslodavaca i sindikata ${ }^{5}$ imali dva suprostavljena pravna shvaćanja. Prvi je, da je riječ o novom postupku kolektivnog pregovaranja na osnovi i za trajanja postojećeg kolektivnog ugovora pa bi trebalo postupak kolektivnog pregovaranja provesti jednako kao i kod sklapanja izvornog teksta kolektivnog ugovora, implicirajući da sklapanje izmjena i dopuna treba biti prema odredbama Zakona o radu, odnosno Zakona o reprezentativnosti udruga poslodavaca i sindikata. Drugo shvaćanje je da je riječ samo o intervenciji u postojeći tekst kolektivnog ugovora, što bi impliciralo primjenu pravila obveznog prava. Zakon o reprezentativnosti udruga poslodavaca i sindikata rješava to pitanje u skladu s pravilima obveznog prava jer je odredbom čl. 10. st. 2. zauzeo stav kako se tijekom trajanja reprezentativnosti sindikata ili prava na zastupljenosti u pregovaračkom odboru pregovori o izmjenama odnosno dopunama sklopljenog kolektivnog ugovora mogu voditi samo između poslodavaca, poslodavaca ili udruga poslodavaca i pregovaračkog odbora sindikata čija je reprezentativnost ili zastupljenost u pregovaračkom odboru utvrđena za sklapanje kolektivnog ugovora, o čijim se izmjenama odnosno dopunama želi pregovarati te koji su potpisnici kolektivnog ugovora. ${ }^{6}$

3 Zakon o radu, Narodne novine, br. 93/14 u daljnjem tekstu ZR

4 Ustavni sud, U-I-3763/2004 od 18.10.2006.

5 Zakon o reprezentativnosti udruga poslodavaca i sindikata, Narodne novine, br. 93/14.

6 U tom smislu i Gotovac, Viktor, Novi Zakon o radu - sudjelovanje radnika u odlučivanju i kolektivni radni odnosi u: Crnić, Ivica; Dika, Mihajlo; Ilak, Vinka; Mihelčić, Gabrijela; Milković, Darko; Sessa, Đuro; Radno i ovršno pravo u praksi, Organizator, Zagreb, 2015., str.41-198. 
Možemo slobodno reći da je primjena pravila ZOO-a zastupljena u svim pitanjima kod ugovora o radu; od sklapanja ugovora, njegovih izmjena te prestanka do pitanja odgovornosti za štetu nastalu u izvršavanju obveza iz ugovora o radu, ali isto tako i kod kolektivnih ugovora. ${ }^{7}$

\section{PRIMJENA ODREDBI ZOO-a PRI SKLAPANJU UGOVORA $O R A D U$}

ZR-om je određeno (čl. 10. st. 1. ZR-a) da se radni odnos zasniva ugovorom o radu čime je radni odnos dobio karakteristike ugovornog odnosa. S obzirom na tu činjenicu, jasno je da se sva pitanja koja se postavljaju u pogledu sklapanja ugovora o radu - trebaju rješavati putem odredbi ZOO-a, pod uvjetom da neko pitanje eventualno nije drugačije uređeno pojedinim izvorom radnog prava. U skladu $\mathrm{s}$ navedenim, kao što to propisuje odredba čl. 247. ZOO-a, ugovor se smatra sklopljen onog trenutka kad se subjekti tog pravnog (radnog) odnosa (poslodavac i radnik) suglase o njegovim bitnim sastojcima. Sudska se praksa također kod sklapanja ugovora o radu poziva na propise obveznog prava; u ugovornim odnosima, pri zasnivanju i ostvarenju prava i obveza ugovorne strane dužne su se pridržavati načela savjesnosti i poštenja (čl. 12. ZOO/91), a sudionici u ugovornom odnosu dužni su izvršavati svoju obvezu i odgovorni su za njezino ispunjenje (čl. 17. st. 1. ZOO/91). ${ }^{8} \mathrm{U}$ tom se smislu ističe da radnik koji prije potpisivanja nije pročitao ugovor o radu nije postupao s pažnjom koja se u prometu zahtijeva (čl. 61. st. 2. $\mathrm{ZOO} / 91)^{9}$

U tom dobrovoljno zasnovanom ugovornom odnosu radnik, prije svega, preuzima obvezu osobno obaviti povjeren mu rad, a poslodavac se obvezuje osigurati radniku posao i za obavljeni mu rad isplatiti plaću. S obzirom na to da je radnik dužan povjeren mu posao osobno obavljati prema nalogu i u skladu s uputama poslodavca, individualni radni odnos karakterizira odnos subordinacije (nadređenosti). Individualni radni odnos je i naplatan društveni odnos. Tu karakteristiku uvjetuje postojanje obveze poslodavca na isplatu plaće, odnosno recipročno postojanje (subjektivnog) prava (objektivnim pravnim poretkom zaštićenog) radnika da mu poslodavac (za obavljeni rad) isplati plaću. Iz prethodno

7 „U provedenom postupku prvostupanjski sud je utvrdio da su stranke u kolektivnom radnom sporu od studenoga 2005. Razlog tog spora je neisplata plaća od strane tužitelja za lipanj, srpanj i kolovoz 2005. Povodom tog spora, 24. studenoga 2005. provedeno je mirenje. Tada je tuženik prihvatio prijedlog tužitelja prema kojem se tužitelj obvezao isplatiti plaće svojim radnicima u skladu s posebnim sporazumom koji je između stranaka sklopljen 28. studenoga 2005. (list 18 i 19 spisa). Utvrđeno je da je mirenje uspjelo uz uvjet poštivanja odredbi sporazuma od 28. studenoga 2005., a u slučaju da poslodavac ne poštuje odredbe rečenog sporazuma, sindikat je ovlašten na poduzimanje daljnjih industrijskih akcija." Vrhovni sud, Gž 2/07-2 od 19.3.2007.

8 Vrhovni sud, Revr-182/08 od 22.10.2008.

9 Vrhovni sud, Rev-2587/88 od 10.6.1999. 
navedenog proizlazi i još jedna njegova karakteristika - on je dvostranoobvezan. I jedna i druga strana (i poslodavac i radnik) istovremeno su u ulozi i vjerovnika i dužnika u tom odnosu. Poslodavac je obvezan isplatiti plaću, a istovremeno ima i pravo potraživati od radnika da osobno obavi povjereni mu posao. Obvezi poslodavca odgovara (subjektivno) pravo radnika potraživati plaću. Pravu poslodavca odgovara obveza radnika na osobno obavljanje rada. Dobrovoljnost u njegovu zasnivanju u skladu je s građanskopravnim (civilističkim) pristupom radnim odnosima, budući da je temelj za zasnivanje individualnlog radnog odnosa ugovor o radu (locatio conductio operarum). Možemo reći da ugovor o radu počiva na obvezi osobnog obavljanja rada u subordiniranom radnom odnosu u kojem je osnovna obveza radnika da radi, a poslodavca da taj rad plati.

Temelj za zasnivanje individualnog radnog odnosa je sklopljen ugovor o radu. Ugovor o radu ima karakteristike koje su identične karakteristikama radnog odnosa, kako je ranije navedeno: to su dobrovoljnost u sklapanju, dvostranoobveznost, naplatnost i subordinacija.

Obveze stranaka ugovora o radu nastaju već od trenutka sklapanja ugovora. To znači da poslodavac radniku koji ne stupi na rad u skladu s dogovorenim, može otkazati ugovor o radu a radnik, ako mu poslodavac onemogućava stupanje na rad, može tražiti da mu se omogući rad u skladu s dogovorenim, uz druga prava iz radnog odnosa koja su do tada dospjela (naknada plaće i sl.). ${ }^{10}$

Iako na prvi pogled ugovor o radu pripada skupini formalnih ugovora ${ }^{11}$ jer je čl. 14. st. 1. ZR-a propisano da se ugovor o radu sklapa u pisanom obliku, ugovor o radu ipak pripada skupini neformalnih ugovora. Naime, zakonodavac je, s ciljem zaštite radnika, propisao da se ugovor o radu ima smatrati sklopljenim, unatoč propustu ugovornih strana da ga sklope u pisanom obliku, ${ }^{12}$ što znači da propuštanje sklapanja ugovora u pisanoj formi ne utječe na njegovo postojanje i valjanost.

U ovakvim su situacijama sudovi znali primjenjivati odredbe ZOO-a kad su stranke ugovora o radu izvršile obveze na koje su se ugovorom obvezale. "Prema shvaćanju ovog suda tužiteljica i tuženik su se, kao ugovorne stranke iz ugovora o radu na određeno vrijeme, sporazumjeli da će tužiteljica raditi kod tuženika samo određeno vrijeme, tj. do 10. prosinca 2004. Tužiteljica je nesporno i radila kod tuženika upravo do tog dana, tuženik joj je isplatio plaću i s tim danom joj je prestao radni odnos pa se na temelju čl. 73. Zakona o obveznim odnosima (,Narodne novine“", broj 53/91, 73/91, 3/94, 7/96, 112/99 i 88/01), koji se primjenjuje u svezi s čl. 6. ZR takav usmeni sporazum stranaka smatra pravovaljano sklopljenim ugovorom o radu na određeno vrijeme (do 10. prosinca 2004.) unatoč tome što stranke

10 „Dužnost ispunjena preuzete ugovorne obveze jedno je od temeljnih načela obveznog prava propisanog odredbom čl.17. ZOO/91 u vezi s čl.10.ZR/04. Osnovna je obveza poslodavca (čl.7.st.1.ZR/04) radniku dati posao te mu za obavljeni rad isplatiti plaću, a radnik je obvezan prema uputama poslodavca,danim u skladu s naravi i vrstom rada, osobno obavljati preuzeti posao." Vrhovni sud, Revr-2055/09 od 3.3.2010.

11 Čl. 14. st. 1. ZR propisano je da se ugovor o radu sklapa u pisanom obliku.

12 Čl. 14. st.2. ZR 
taj ugovor nisu zaključile u pisanoj formi. To stoga što su tužiteljica i tuženik, kao ugovorne stranke, u cijelosti ispunile obveze iz tog ugovora o radu." ${ }^{\text {“13 }}$

S tim u vezi, potrebno je spomenuti i presumpciju prema kojoj će se smatrati da je poslodavac s radnikom sklopio ugovor o radu ako s radnikom sklopi ugovor za obavljanje posla koji s obzirom na narav i vrstu rada te ovlasti poslodavca da ima obilježje posla za koji se zasniva radni odnos (pod uvjetom da poslodavac ne dokaže suprotno). ${ }^{14}$ Ova presumpcija nije bila predviđena ZR/95, već je uvedena Zakonom o izmjenama i dopunama ZR iz 2003. (Narodne novine, br. 114/03), a posljedica je činjenice da se u praksi često javljaju slučajevi simuliranja nekih ugovora obveznog prava (najčešće ugovora o djelu) sa sadržajem koji nedvojbeno upućuje na ugovor o radu. ${ }^{15}$

Kao i za svaki drugi ugovor, tako i za ugovor o radu bilo koja od stranaka može u sudskom postupku osporavati njegovu valjanost, bilo da traži poništenje zbog mana volje (čl. 279. do 285. ZOO-a) ili utvrđenje ništetnosti (čl. 322. ZOO-a). ${ }^{16}$ Potrebno je istaknuti da se u tom slučaju ne bi radilo o zahtjevu za sudskom zaštitom prava prema odredbama ZR-a, već prema odredbama ZOO-a, pa stoga radnik nije obvezan prethodno obraćati poslodavcu se radi zaštite prava niti je vezan zakonskim rokovima iz ZR-a. ${ }^{17}$

Tijekom trajanja ugovora o radu, između njegovih stranaka mogu nastati i ugovorni odnosi koji ne proizlaze iz sadržaja ugovora o radu u smislu čl. 15. ZR. Primjerice, kad poslodavac pozajmi određeni iznos novca radniku, tad je među njima sklopljen ugovor o zajmu u smislu čl. 499. st. 1. ZOO pa su odredbe tog Zakona relevantne za razrješenje tog odnosa, a ne odredbe ZR niti ugovora o radu.

Posebne su vrste ugovornih odnosa nastaju kod plaćanja troškova obrazovanja radnika. Često se obrazovanje čije troškove snosi poslodavac uvjetuje određenim obvezama radnika. Najčešće se radi o obvezi ostanka u radnom odnosu kod poslodavca određeno vrijeme nakon okončanja obrazovanja, a ako ovu obvezu ne ispuni, ima obvezu povrata poslodavcu novčanih sredstava uloženih u to obrazovanje. Ponekad je dužan vratiti ta sredstava u cijelosti, a ponekad razmjerno vremenu provedenom na radu nakon dovršetka obrazovanja u odnosu na vrijeme koje je bio dužan ostati. U svakoj onoj situaciji kada ništa nije posebno propisano, u pogledu svih ovih pitanja, sud će u slučaju spora procjenjivati kakva prava

13 Vrhovni sud, Revr 645/2009-2 od 15.9.2009.

14 Čl. 10. st. 2. ZR

15 Tako i Vera Babić u radu Zakon o izmjenama i dopunama Zakona o radu (ZIDZOR)- novine u radnom zakonodavstvu, Godišnjak 10. 2003., str. 207.

16 „Tužitelj tvrdi da je prilikom sklapanja ugovora o radu na određeno vrijeme bio u zabludi, odnosno da ga je tuženik, postupajući prijevarno, doveo u zabludu, tako da tužbeni zahtjev usmjeren na poništenje ugovora o radu na određeno vrijeme temelji na odredbama čl. 111. i 112. u svezi sa čl. 65. Zakona o obveznim odnosima ("Narodne novine", broj 53/91, 3/94, 7/96 i 112/99 - dalje: ZOO). Kraj izloženog činjeničnog utvrđenja da tužitelj prilikom sklapanja ugovora o radu na određeno vrijeme nije bio u zabludi, a niti je tuženik pri tom postupao prijevarno, pravilno su nižestupanjski sudovi primijenili materijalno pravo kada su odbili tužbeni zahtjev.“ Vrhovni sud, Revr 165/05-2 30.3.2005.

17 U tom smislu vidjeti i Vrhovni sud, Revr-762/02 od 19.12.2002. i Rev-2119/00 od 21.2.2001. 
i obveze proizlaze iz ugovornog odnosa radnika i poslodavca, imajući pri tom u vidu cilj i smisao odredaba Zakona o radu i onih drugih pravnih izvora koji pitanje obrazovanja eventualno uređuju, pri čemu će sud obvezno i supsidijarno primjenjivati odredbe ZOO-a. ${ }^{18}$

\subsection{Sadržaj ugovora o radu}

ZR izrijekom propisuje (čl. 15) što ugovor o radu u pisanom obliku, odnosno potvrda o sklopljenom ugovoru o radu mora sadržavati. Riječ je o objektivno bitnim sastojcima ugovora koji su prema prisilnom propisu (ZR) nužni za nastanak ugovora i njih se utvrđuje, odnosno izvodi iz zakonskog pojma, odnosno definicije pojedinog tipa ugovora. ${ }^{19}$

Za ovo propisivanje sadržaja ugovora o radu možemo reći da je u skladu sa čl. 248. st. 2. ZOO kojim je propisano da su odredba propisa kojim se, djelomično ili u cijelosti, određuje sadržaj ugovora sastavni dijelovi tih ugovora te ih upotpunjuju ili stupaju na mjesto ugovornih odredbi koje nisu u skladu s njima.

U tom smislu ZR određuje da ugovor o radu odnosno potvrda o sklopljenom ugovoru o radu, mora sadržavati uglavke o: strankama te njihovu prebivalištu; mjestu rada; a ako ne postoji stalno ili glavno mjesto rada, onda napomenu da se rad obavlja na različitim mjestima; nazivu, naravi ili vrsti rada na koji se radnik zapošljava ili kratak popis ili opis poslova; danu otpočinjanja rada, očekivanom trajanju ugovora, u slučaju ugovora o radu na određeno vrijeme; trajanju plaćenoga godišnjeg odmora na koji radnik ima pravo, a u slučaju kad se takav podatak ne može dati u vrijeme sklapanja ugovora, odnosno izdavanja potvrde, načinu određivanja trajanja toga odmora; otkaznim rokovima kojih se mora pridržavati radnik, odnosno poslodavac, a u slučaju kad se takav podatak ne može dati u vrijeme sklapanja ugovora, odnosno izdavanja potvrde, načinu određivanja otkaznih rokova; osnovnoj plaći, dodacima na plaću te razdobljima isplate primanja na koja radnik ima pravo, trajanju redovitog radnog dana ili tjedna.

Uglavci o trajanju plaćenog godišnjeg odmora, otkaznim rokovima, osnovnoj plaći, dodacima na plaću, razdobljima isplate primanja te trajanju redovitog radnog dana ili tjedna, mogu se urediti tako da se ugovorom, odnosno potvrdom, uputi na odgovarajuće zakone, druge propise, kolektivne ugovore ili pravilnike o radu koji uređuju ta pitanja. ${ }^{20}$

Kada u ugovoru o radu odredbe o plaći nisu u potpunosti određene, ugovor o radu zbog tih manjkavosti nije ništetan, jer se i u tom slučaju plaća može odrediti na jedan od načina koje predviđa odredba čl. 90. ZR. ${ }^{21}$ Pri tomu se sudovi također

18 Trbojević, Goran, op.cit. str. 20.

19 Općenito o sadržaju pravnih poslova vidjeti kod; Slakoper, Zvonimir i Gorenc, Vilim uz suradnju Maje Bukovac Puvača, Obvezno pravo, Opći dio, Novi informator, Zagreb, 2009.

20 Čl. 15. st. 2. ZR-a

21 Žs u Koprivnici Gž 77/00 od 1.6.2000. 
služe i odredbama ZOO-a koje propisuju kakav mora biti predmet obveze, ističući da je dovoljno da je zahtjev radnika (ili službenik) odrediv. ${ }^{22}$

Skrećemo pažnju da obično poslodavac priprema i predlaže tekst ugovora tako da će u skladu s odredbom čl. 320. st. 1. ZOO-a, kojom je određeno da u slučaju kada je ugovor sklopljen prema unaprijed odštampanom sadržaju ili kad je ugovor na drugi način pripremila i predložila jedna ugovorna strana, nejasne odredbe tumačiti u korist druge strane - radnika.

\section{UGOVOR O RADU - UGOVOR O DJELU}

Vrlo često se u kontekst ugovora o radu, stavlja i ugovor o djelu. Naime, prigovora se da poslodavci zloupotrebljavaju svoj položaj i umjesto ugovora o radu sklapaju ugovore o djelu. Stoga ćemo u nastavku ukratko iznijeti razlike između tih ugovora.

Kao što smo uvodno istaknuli, ugovorom o radu zasniva se radni odnos i njime se poslodavac obvezuje radniku dati posao i za obavljeni posao isplatiti mu plaću, a radnik se obvezuje osobno obaviti posao po uputi poslodavca (čl. 7. st. 1. ZR-a). Iz navedenog vidimo da su bitna obilježja ugovora o radu; osobno obavljanje rada, obavljanje samog rada kao bitnog elementa, subordinacija radnika prema poslodavcu te isplata mjesečne plaće.

Ugovorom o djelu, kao ugovorom obveznog prava reguliranog čl. 590 . ZOO-a, jedna se strana (izvođač) obvezuje obaviti određeni posao, kao što je izrada ili popravak neke stvari ili izvršenja kakvog fizičkog ili intelektualnog rada, a druga strana (naručitelj) se obvezuje mu za to platiti naknadu. Za ugovor o djelu karakteristično je da izvoditelj ne prima mjesečnu plaću već ugovorenu naknadu i da ne postoji subordinacija izvoditelja radova prema naručitelju kakva je između radnika i poslodavca (postoji uputa naručitelja, ali izvođač ima veću samostalnost nego radnik koji je pod svakodnevnim 8 satnim nadzorom), pri čemu nije bitan sam rad već rezultat rada.

Da bi zaštitio radnika kao slabiju ugovornu stranu, zakonodavac je čl. 10. st. 2. ZR-a propisao da će se smatrati da je poslodavac s radnikom sklopio ugovor o radu ako s njim sklopi ugovor za obavljanje posla koji s obzirom na narav i vrstu rada te ovlasti poslodavca ima obilježje posla za koje se zasniva radni odnos (osim ako poslodavac ne dokaže suprotno). Narav i vrsta rada na temelju kojih se ocjenjuje je li sklopljen ugovor o radu ili ne, promatra se kroz okolnost radi li se o poslu

22 „Iznos naknade za taj rad valja utvrditi usporedbom s iznosom naknade za prekovremeni rad koja je u tom razdoblju plaćana od strane države drugim državnim službenicima odgovarajućeg zanimanja odnosno stručne spreme. Riječ je, naime, o obvezi koja je odrediva a koja se takvom usporedbom može i u cijelosti odrediti (čl. 46. st. 2. Zakona o obveznim odnosima - "Narodne novine", broj 53/91., 73/91., 3/94., 7/96., 112/99. i 88/01. - dalje: ZOO) koji se primjenjuje na temelju čl. 6. Zakona o radu ("Narodne novine", broj 38/95., 54/95. ispr., 64/95. - ispr., 17/01., 82/01. i 114/03. - dalje: ZR).“ Vrhovni sud, Revr 671/2007-2 od 28.11. 2007. 
koji se redovito obavlja, je li riječ o svakodnevnim i zadatcima koji se obavljaju u kontinuitetu ili povremenim zadacima za koje se prima mjesečna plaća ili ugovorena naknada.

Kratko, ako radnik svakodnevno izvršava radne zadatke, te zadatke dobiva od poslodavca (dakle prisutan je element subordinacije) i za to dobiva mjesečnu plaću - tad je nedvojbeno riječ o ugovoru o radu, a ne o ugovoru o djelu neovisno kako je nazvan. O ugovoru o djelu bi se radilo ako poslodavac od neke osobe naruči da mu nešto napravi, pri čemu on to ne radi po direktnom svakodnevnom nalogu i za napravljeno mu se isplaćuje naknada, a ne plaća.

$\mathrm{S}$ tim u vezi u nastavku ističemo jedan zanimljiv (i indikativan sudski predmet). Općinski radni sud u Zagrebu je u postupku Pr-902/09 zaključio da je tužiteljica s tuženikom imala zaključen ugovor koji ima sva bitna obilježja ugovora iz radnog odnosa jer je tužiteljica za tuženika svakodnevno obavljala posao pomoćnika glavnog urednika u sklopu koga je svakodnevno vodila i organizirala rad od novinara do deska, planirala i vodila brigu o izvršavanju dnevno postavljenih zadataka od novinara, odobravala objavljivanje novinskih članaka, sudjelovala u kreiranju kadrovske politike itd. Županijski sud u Zagrebu je presudom Gžr-266/11 od 12. travnja 2011. odbio žalbu tuženika i potvrdio prvostupanjsku presudu te uz utvrđenje suda prvog stupnja utvrdio da je tužiteljica imala svoju radnu sobu kod tuženika, da je imala ugovoreno radno vrijeme i fiksnu bruto plaću mjesečno. Vrhovni je sud RH svojim rješenjem, br. Revr-1312/11 od 21. prosinca 2011. ukinuo navedene presude smatrajući da zbog pogrešne pravne ocjene činjenično stanje u provedenom postupku nije u potpunosti utvrđeno, odnosno smatra da je trebalo cijeniti činjenicu da je tužiteljica u statusu samostalne djelatnosti i da je kao takva izravni obveznik plaćanja doprinosa, poreza na dohodak i prireza, da je u ugovoru naznačeno da će autor poslove obavljati u vlastitim radnim prostorijama i na vlastitim sredstvima rada, te da će se naknada isplaćivati za obavljanje poslova za temelju računa kojeg ispostavlja autor. ${ }^{23}$

\section{PROMJENE UGOVORA O RADU 24}

S obzirom na to da ugovor o radu nastaje suglasnošću volja ugovornih strana, niti jedna ugovorna strana ne može jednostrano izmijeniti sadržaj ugovora, osim u slučaju otkaza uz ponudu izmijenjenog ugovora o radu. Izjava jedne ugovorne strane da mijenja sadržaj ugovora ne tiče se druge ugovorne strane. ${ }^{25} \mathrm{Na}$ koji se onda način mijenjaju odredbe ugovora o radu?

23 Stav je Vrhovnog suda da je ovdje riječ o ugovoru o novinarskoj suradnji u smislu odredbe čl. 2. st. 1. podstav. 7. Zakona o medijima (Narodne novine, br. 59/04) prema kojoj je novinar osoba koja se bavi prikupljanjem, obradom, oblikovanjem ili razvrstavanjem informacija za objavu putem medija, te je zaposlena kod nakladnika na temelju ugovora o radu ili obavlja novinarsku djelatnost kao samostalno zanimanje, u skladu sa zakonom.

24 Literatura: Ruždjak, Marijan, Obveznopravni elementi ugovora o radu, Radno pravo, Zbornik radova Konferencije o radnim odnosima u Republici Hrvatskoj, Zagreb, 12. prosinca 2012.

25 Vrhovni sud, Revr-748/05 od 11.1.2006. 
Stranke ugovora o radu mogu njegov sadržaj mijenjati na različite načine, počevši od sporazuma (aneksa), konkludentim radnjama, otkazom jedne strane uz ponudu izmijenjenog ugovora drugoj strani ili izmjenom nekog od izvora radnog prava koji je regulirao sadržaj ugovora o radu.

Smatramo da ćemo to najbolje prikazati na konkretnom slučaju, primjerice kod izmjene odredbi o plaći iz ugovora o radu.

\subsection{Suglasne izmjene odredbi o plaći koja je određena ugovorom o radu}

Kad su radnik i poslodavac suglasni s izmjenom odredbi koje reguliraju pitanje plaće, to se može učiniti sklapanjem novog ugovora o radu ili dodatkom (aneksom) postojećem ugovoru. U novom ugovoru je dobro navesti da se njegovim sklapanjem izvan snage stavlja dosadašnji ugovor, a ako se sklapa aneks postojećem ugovoru, u njemu će se navesti da se njime mijenja odredba o visini plaće u starom ugovoru. Nadalje, poželjno je naznačiti datum od kad se primjenjuje taj aneks. Da bi izjava volje za promjenom sadržaja ugovora o radu proizvela pravni učinak, ona mora biti učinjena slobodno i ozbiljno. ${ }^{26}$

U radnom su pravu vrlo česte izmjene ugovora o radu konkludentnim radnjama. Primjerice, kad poslodavac radniku umjesto ugovorene plaće isplaćuje veću plaću, a radnik bez izričitog pisanog ili usmenog očitovanja, pristane na takvu izmjenu. Obje ugovorne strane izmjene prihvaćaju i takvo stanje ostaje trajno.

\subsection{Otkaz ugovora o radu uz ponudu izmijenjenog ugovora}

Ako dogovor o izmjeni ugovora nije postignut, poslodavac nije ovlašten jednostrano mijenjati plaću radnika. U tom smislu je i pravno shvaćanje sudske prakse; «Poslodavac nije ovlašten jednostrano mijenjati bitnu ugovornu odredbu (uglavak), pa ga na to ne ovlašćuje niti «stanje nužde» uzrokovano određenim poslovnim poteškoćama». ${ }^{27}$ Stoga će, ako nije postignut dogovor, poslodavac morati otkazati ugovor o radu i radniku dati ponudu za sklapanjem novog ugovora s manjom plaćom. Poslodavac pri tom mora poštovati zakonsku proceduru otkazivanja ugovora o radu te u slučaju sudskog postupka dokazati postojanje opravdanog razloga za otkaz.

26 „Prema odredbi čl. 247. Zakona o obveznim odnosima („Narodne novine“ 35/05 i 41/08 dalje: ZOO), kao općeg propisa građanskog prava, koji se na temelju odredbe čl. 6. st. 4. ZR primjenjuje i na sklapanje, valjanost, prestanak i druga pitanja u vezi s ugovorom o radu, ugovor je sklopljen kad su se ugovorne strane suglasile o bitnim sastojcima ugovora. Ugovor je sklopljen prihvaćanjem ponude koja sadrži sve bitne sastojke ugovora onog časa kad ponuditelj primi izjavu ponuđenika da prihvaća ponudu (čl. 253. st. 1. ZOO.) U konkretnoj situaciji, prihvaćanjem ponude za sklapanje ugovora za drugo radno mjesto tužitelj se je s tuženikom sporazumio o izmjeni ranijeg ugovora o radu u pogledu radnog mjesta te drugih bitnih sastojaka ugovora o radu te u toj situaciji tuženik tužitelju nije ni trebao otkazivati raniji ugovor, a niti ponuda ugovora predstavlja otkaz ugovora o radu." Vrhovni sud, Revr 664/13-216.4.2014.

27 Žs u Varaždinu Gž-714/03 od 24. 6. 2003. 
Otkaz se prosuđuje prema pravilima o redovitom otkazu što znači da će biti valjan ako postoje neki od razloga za redoviti otkaz. U tom smislu u sudskoj se praksi ističe: „Potpisom Ugovora o radu obje stranke preuzimaju ugovorom predviđena prava i obveze. Niti jednom tijekom postupka nije dovedena u sumnju činjenica da je tužitelj ispunjavao preuzete obveze, no tuženica, međutim, to nije učinila, već je samovoljno od 1. studenoga 1997. počela tužitelju mjesečno isplaćivati plaću nižu od ugovorene. Mogućnost za izmjenu cijelog ugovora ili njegovog dijela predviđena je odredbom čl. 114. ZR, pri čemu poslodavac može otkazati ugovor o radu s ponudom izmijenjenog ugovora, ali treba navesti razloge za otkazivanje ugovora o radu ukoliko tužitelj ne bi prihvatio ponudu da se ugovor u cijelosti ili djelomično izmijeni. Kako je tuženik 17. 10. 1997. donio odluku o otkazu s ponudom izmijenjenog ugovora, a da za otkaz nije naveo nikakav ni poslovno uvjetovani a ni osobno uvjetovani razlog, već je samo ukazao na mogućnost da otkaz neće vrijediti ukoliko tužitelj prihvati sklapanje novog ugovora o radu s nižom plaćom, to su nižestupanjski sudovi pravilno utvrdili da je pobijana odluka nezakonita. U slučaju kada poslodavac u smislu odredbe čl. 114. st. 1. ZR otkazuje Ugovor o radu i istovremeno predloži zaposleniku sklapanje Ugovora o radu s nižom plaćom dužan je obrazložiti svoju ponudu razlozima za otkaz. Kada poslodavac donese odluku o otkazu ne poštujući zakonsku odredbu, kao što je to u konkretnom slučaju, tada je povrijedio pravo tužitelja iz radnog odnosa te tužitelj opravdano zahtijeva zaštitu svojih osnovnih prava iz radnog odnos pred sudom." 28

Razloge je dakle potrebno konkretno naznačiti već u samom obrazloženju odluke o otkazu ugovora o radu. Naglašavamo da se mora raditi o opravdanim razlozima, a to znači da je poslodavac u takvim financijskim poteškoćama zbog kojih nije u mogućnosti isplaćivati plaću u visini koju je do sada isplaćivao. Pritom sama činjenica da poslodavac nije ostvario planirani promet dobiti, ne predstavlja opravdan razlog za umanjenje plaće radnicima. ${ }^{29}$

Premda se na prvi pogled ne čini da bi se odredbe ZOO primjenjivale kod otkaza ugovora o radu kao specifičnog instituta ZR-a, u sudskoj praksi nailazimo na odluke u kojima se sudovi pozivaju na pojedine odredbe ZOO-a, od forme samog raskida ugovora o radu do $^{30}$ odredbe o zabrani vršenja prava iz obveznih

28 Vrhovni sud, Rev 1951/00 od 23. 5. 2001.

29 U odluci Vrhovnog suda Revr 365/07 od 19. 11. 2007. ističe se da neostvarivanje planiranog prometa dobiti društva je poslovni rizik kojeg društvo ne može prebaciti na teret radnika smanjenjem njihove osnovne plaće.

30 „Na sklapanje, valjanost, prestanak ili drugo pitanje u svezi s ugovorom o radu primjenjuju se u smislu čl. 6. ZR-a u skladu s naravi tog ugovora opći propisi obveznog prava. Prema odredbi čl. 68. Zakona o obveznim odnosima ("Narodne novine" broj 53/91, 73/91, 3/94, 7/96. i 112/99), koji se u ovom slučaju primjenjuje, formalni ugovori mogu biti raskinuti neformalnim sporazumom, izuzev ako je za određeni slučaj zakonom predviđeno što drugo, ili ako cilj zbog kojega je propisana forma za sklapanje ugovora zahtijeva da raskid ugovora bude obavljen u istoj formi. Kada je u pitanju otkaz ugovora o radu zakonom (odredbom čl. 111. st. 1. ZR) je izrijekom propisano da mora imati pisani oblik. Usmeni otkaz ugovora o radu stoga nije dopušten." Vrhovni sud, Revr 784/2005-2 od 12.4.2006. 
odnosa protivno cilju zbog kojeg je ono zakonom ustanovljeno ili priznato, kako bi protumačili ponašanje stranaka ugovora o radu prije samog otkaza ugovora. ${ }^{31}$

Neovisno o tome je li prihvatio ponudu za sklapanjem novog ugovora o radu sa smanjenom plaćom ili nije, radnik ima pravo u sudskom postupku osporavati valjanost otkaza (čl. 123. st. 2. ZR-a).

\subsection{Smanjenje plaće određene kolektivnim ugovorom}

S obzirom na to da se zakonom obično uređuju samo osnovna pitanja odnosa između radnika i poslodavca, polazeći pritom od temeljne zamisli da ugovornu autonomiju stranaka radnog odnosa treba ograničiti radi zaštite radnika kao ekonomski i socijalno slabije strane radnog odnosa, kolektivni su ugovori izvor radnog prava koji omogućava da se zaštita radnika dodatno proširi. Oni su posebno važni i za poslodavce jer uređujući plaće poslodavcima osiguravaju relativnu izvjesnost glede planiranja troškova radne snage, kao važnoga dijela troškova poslovanja. ${ }^{32}$

Ako poslodavac nije u mogućnosti ispuniti preuzete obveze iz kolektivnog ugovora, može pokrenuti inicijativu za izmjene i dopune pojedinih odredaba ugovora ili otkazati kolektivni ugovor. Napominjemo da se može otkazati kolektivni ugovor koji je sklopljen na neodređeno vrijeme, a da se kolektivni ugovor sklopljen na neodređeno vrijeme može otkazati samo ako je ta mogućnost predviđena ugovorom. Ako postoji mogućnost otkazivanja, kolektivni ugovor mora sadržavati uglavke o otkaznim razlozima i rokovima. U takvom slučaju za mogućnost otkaza bilo bi nužno da nastupi otkazni razlog koji je naveden u kolektivnom ugovoru. Obično se u kolektivnim ugovorima kao razlog otkazivanja propišu promijenjene gospodarske okolnosti, kršenje obveze ugovora i sl. Poslodavac može predložiti ugovaranje nove plaće u skladu sa svojim mogućnostima.

31 „Odredbom čl. 13. Zakona o obveznim odnosima ("Narodne novine”, broj 53/91, 73/91, 113/93, 3/94, 7/96, 91/96, 112/99 i 88/01, - dalje ZOO), koji se na temelju odredbe čl. 6. ZR primjenjuje i na ugovor o radu, propisano je da je zabranjeno vršenje prava iz obveznih odnosa protivno cilju zbog kojeg je ono zakonom ustanovljeno ili priznato. Pravo poslodavca iz čl. 106. st. 1. podstavak 1 . ZR da zbog organizacijskih razloga otkaže ugovor o radu, uz poštivanje zakonskih kriterija iz st. 3. čl. 106. ZR, ima za cilj da svi radnici koji obavljaju poslove na koje se organizacijske promjene odnose budu u jednakom položaju (ravnopravni) te da se ugovor otkaže onima, kako je već navedeno, koji imaju kraći radni staž, manje godina života i manje obveze uzdržavanja. U slučaju da je poslodavac u konkretnom slučaju doista prije izvršene statusne promjene i s njom u vezi izvršenih organizacijskih promjena i donošenja Programa zbrinjavanja viška radnika, određeni broj radnika koji obavljaju poslove na koje se organizacijske promjene odnose prebacivao na druge poslove koji nisu zahvaćeni organizacijskim promjenama zato da im ne bi otkazao ugovor o radu, moglo bi se zaključiti da je na taj način zlorabio pravo da svim radnicima u odnosu na čije poslove se organizacijske promjene odnose otkaže ugovor o radu pod jednakim, zakonom propisanim, uvjetima izigravajući na taj način cilj propisan odredbom čl. 106. st. 1. podstavak 1. i st. 3. ZR.“"Vrhovni sud Revr 597/09-2 od 22.10.2009.

32 Potočnjak, Željko, Otvorenja pitanja sklapanja i primjene kolektivnih ugovora, Informator, br. 55564-5565 str.1. 
Sindikat kao ugovorna strana ima izbor između prihvaćanja ili odbijanja inicijative za pregovore. Ako sindikat odbije takvu inicijativu, poslodavac može otkazati sklopljeni kolektivni ugovor u rokovima predviđenim tim ugovorom. No, takav postupak poslodavca znači da ni sindikat više ne obvezuju eventualno ugovorene klauzule o socijalnom miru. ${ }^{33}$ Da bi otkaz kolektivnog ugovora bio valjan, on se mora dostaviti drugoj ugovornoj strani, ali i ministarstvu nadležnom za rad ili županijskom uredu nadležnom za poslove rada, ovisno o području primjene, jer je propisano da se svaki kolektivni ugovor kao i svaka njegova promjena dostavlja upravo tim nadležnim tijelima.

\subsection{Smanjenje plaće određene pravilnikom o radu}

Ako plaća nije uređena ugovorom o radu ni kolektivnim ugovorom, poslodavac koji zapošljava više od 20 radnika dužan ju je utvrditi pravilnikom o radu. Naime, ZR-om je propisano da se pravilnikom o radu uređuje plaća, organizacija rada, postupak i mjere za zaštitu dostojanstva radnika, kao i druga pitanja važna za radnike zaposlene kod poslodavca. Prije donošenja pravilnika o radu poslodavac je dužan provesti postupak savjetovanja sa radničkim vijećem (čl. 150. st. 1. ZR-a).

Stoga poslodavac prije donošenja pravilnika mora radničkom vijeću dostaviti sve podatke o namjeravanoj odluci, što uključuje i sam nacrt pravilnika. ${ }^{34}$ Radničko vijeće dužno je u roku od 8 dana dati svoje očitovanje jer se u protivnom smatra da nema primjedbi. Poslodavac nije vezan primjedbama radničkog vijeća, niti se je na njih dužan očitovati, pa pravilnik može donijeti unatoč protivljenju radničkog vijeća.

Doneseni pravilnik o radu ne može stupiti na snagu prije nego je objavljen u skladu s odredbama pravilnika o načinu objave pravilnika o radu. ${ }^{35}$ To znači da se pravilnik mora objaviti tako da bude dostupan na uvid radnicima i izložen na vidljivom mjestu u prostorijama u kojima oni redovito borave tijekom radnog vremena. Ako postoje opravdani razlozi zbog kojih pravilnik ne može objaviti na opisani način, poslodavac je o donošenju pravilnika dužan radnike izvijestiti pisanom objavom. Pravilnik je dužan dostaviti i članovima radničkog vijeća odnosno sindikalnom povjereniku ako nije izabrano radničko vijeće.

Ako je u skladu s odredbom čl. 15. st. 2. ZR-a u ugovoru o radu umjesto uglavka o plaći upućuje na odgovarajuću primjenu pravilnika o radu koji određuje ta pitanja, tad će izmjena pravilnika o radu, izmijeniti i odredba o plaći radnika. ${ }^{36} \mathrm{I}$

33 U tom smislu i Zuber, Marija, Plaće i naknade u propisima radnog i socijalnog prava, u zborniku Radni odnosi - novine u radno-socijalnom zakonodavstvu, Zagreb, 2009. Inženjerski biro d.d., str. 247.

34 Ruždjak, Marijan Zakon o radu, Poslovni zbornik, Zagreb, 2003., str. 344.

35 Nar. nov., br. 146/14.

36 „Tužiteljica i sama u reviziji navodi da je tuženik za obavljeni rad bio dužan tužiteljici isplatiti plaću određenu ugovorom o radu, sukladno Pravilniku o radu i odredbama Zakona o radu. Ovaj sud je suglasan s pravnim shvaćanjem tužiteljice da je ugovor o radu temelj 
u sudskoj praksi nalazimo odluke u tom smislu: «Ako je ugovorom o radu određeno da će se pravo radnika na plaću i druge naknade određivati u skladu s Pravilnikom o radu, naknade izmjene Pravilnika o radu primjenjivat će se bez obzira na to što je naknada plaće za troškove prijevoza određena na nepovoljniji način.» ${ }^{37}$ Jednako pravno shvaćanje nalazimo i u odluci Vrhovnog suda Revr 804/2006 od 23. siječnja 2008.» Tužitelj neosnovano ustraje u prigovoru da je tuženik jednostranom odlukom izmijenio plaću tužitelja, budući da je Ugovorom o radu predviđeno da će se plaća isplaćivati prema Pravilniku o plaćama i drugim primanjima zaposlenika od 15. lipnja 1998., a sve citirane Odluke o uređenju elemenata za obračun plaće radnika na radnom mjestu vozača autobusa po svojoj pravnoj naravi su akti kojima se uređuje plaća i u rangu su Pravilnika o plaćama. Te su Odluke donesene nakon savjetovanja s radničkim vijećem, kako to propisuje odredba čl. 145. Zakona o radu, pa su neosnovani i prigovori da su donesene bez suglasnosti radničkog vijeća.»

Slažemo se s razmišljanjem da u tom slučaju poslodavac nije dužan posegnuti za otkazivanjem ugovora s ponudom izmijenjenog ugovora. ${ }^{38}$ Napominjemo da pravo na sudsku zaštitu protiv nezakonitog pravilnika o radu ima radničko vijeće. Ono može tražiti da se nezakoniti pravilnik o radu ili neke njegove odredbe oglase nevažećim. ${ }^{39}$ Ako kod poslodavca nije utemeljeno radničko vijeće, to pravo ima sindikalni povjerenik.

prava i obveza iz radnog odnosa. Opća načela obveznog prava na koja se tužiteljica poziva primjenjuju se i na ugovor o radu (arg. iz čl. 10. ZR), kao što je načelo slobode uređivanja obveznih odnosa iz čl. 10. Zakona o obveznim odnosima ("Narodne novine" 53/91, 73/91, 3/94, 7/96. i 112/99. - dalje: ZOO), koji je tada bio na snazi, te dužnost ispunjena obveze u smislu čl. 17. st. 1. ZOO.

Tužiteljica pozivom na odredbe čl. 17. ZOO navodi da jedna ugovorna strana ne može mijenjati ugovorne odredbe i da se obveza može ugasiti samo suglasnošću volja sudionika ili na temelju zakona. Tuženik međutim nije jednostrano mijenjao ugovor o radu niti je prestala njegova obveza isplate plaće tužiteljici. Ugovorom o radu i Pravilnikom o radu je plaća određena brojem bodova, a ne u određenom novčanom iznosu. Plaća nije ugovorena u kunama ni za travanj 1999., nego je obračunata sukladno Ugovoru o radu i Pravilniku o radu tako da je broj bodova (1945) pomnožen s vrijednošću boda, a koju vrijednost je odredila uprava. Nema razloga zbog kojega se plaća ne bi obračunavala na takav ugovoreni način i za vremensko razdoblje koje slijedi nakon travnja 1999. Sklapanjem ugovora o radu tužiteljica je ugovorila s tuženikom da vrijednost boda za svaki mjesec određuje uprava, a u ovoj parnici zahtijeva da joj se plaća obračuna i isplati prema vrijednosti boda za travanj 1999. i za vremensko razdoblje navedeno u tužbi, a što je suprotno onome što je ugovoreno.“ Vrhovni sud, Revr 225/07-2 od 25.4.2007.

37 Ustavni sud RH U-III_3908/03 od 24. 11. 2005.

$38 \mathrm{U}$ tom smislu i Ruždjak, Marijan Plaće, otpremnine i druge naknade iz radnog odnosa, Godišnjak 6, 1999. str.298.

39 Čl. 27. st. 6. ZR-a 


\section{STJECANJE BEZ OSNOVE}

Povodom sporova proizašlih iz ugovora o radu pojavljuju se situacije kod kojih je potrebno primijeniti obveznopravni institut stjecanja bez osnove koji reguliraju odredbe čl. 1111-1120 ZOO-a.

\subsection{Zaštita dostojanstva radnika}

Postupak i mjere zaštite dostojanstva radnika od uznemiravanja i spolnog uznemiravanja uređuju se posebnim zakonom, kolektivnim ugovorom, sporazumom sklopljenim između radničkog vijeća i poslodavca ili pravilnikom o radu (čl. 134., st. 1. ZR-a). Poslodavac koji zapošljava najmanje dvadeset radnika dužan je imenovati osobu koja je osim njega ovlaštena primati i rješavati pritužbe vezane uz zaštitu dostojanstva radnika. Imenovana osoba ili poslodavac dužna je u roku utvrđenom kolektivnim ugovorom, sporazumom sklopljenim između radničkog vijeća i poslodavca ili pravilnikom o radu, a najkasnije u roku osam dana od dostave pritužbe, ispitati pritužbu i poduzeti sve potrebne mjere primjerene pojedinom slučaju radi sprječavanja nastavka uznemiravanja ili spolnog uznemiravanja ako utvrdi da ono postoji.

Ako poslodavac u propisanom roku ne poduzme mjere za sprječavanje uznemiravanja ili spolnog uznemiravanja ili ako su mjere koje je poduzeo očito neprimjerene, radnik koji je uznemiravan ili spolno uznemiravan, ima pravo prekinuti rad dok mu se ne osigura zaštita, pod uvjetom da je u daljnjem roku od osam dana zatražio zaštitu pred nadležnim sudom (čl. 134. st. 4. ZR). Ako postoje okolnosti zbog kojih nije opravdano očekivati da će poslodavac zaštititi dostojanstvo radnika, radnik nije dužan dostaviti pritužbu poslodavcu, već ima pravo prekinuti rad pod uvjetom da je zatražio zaštitu pred nadležnim sudom i o tome obavijestio poslodavca u roku od osam dana od dana prekida rada (čl. 134. st. 5. ZR).

Za vrijeme prekida rada radnik ima pravo na naknadu plaće u visini kao da je radio. Međutim, ako je pravomoćnom sudskom odlukom utvrđeno da nije povrijeđeno pravo dostojanstva radnika, poslodavac može zahtijevati povrat isplaćene naknade (čl. 134. st. 7. ZR-a). Tad će se primijeniti obveznopravni institut stjecanja bez osnove iz čl. 1111. ZOO-a koji st. 1. propisuje da kad dio imovine neke osobe na bilo koji način prijeđe u imovinu druge osobe, a taj prijelaz nema osnove u nekom pravnom poslu, odluci suda, odnosno druge nadležne vlasti ili zakonu, stjecatelj je dužan vratiti ga, odnosno, ako to nije moguće naknaditi vrijednost postignute koristi. Nadalje, st. 3. istog članka, određeno je da obveza vraćanja, odnosno nadoknade vrijednosti nastaje i kad se nešto primi s obzirom da osnovu koja se nije ostvarila ili koja je kasnije otpala. U ovom bi se slučaju radilo o osnovi koja se nije ostvarila jer je radnik pravomoćnom presudom odbijen sa zahtjevom da je povrijeđeno njegovo pravo dostojanstva.

Radnik bi kao stjecatelj u ovom slučaju bio nepošten od pravomoćnosti sudske odluke kojom je odbijen njegov zahtjev za zaštitom dostojanstva, što znači da je 
prema čl. 1115. ZOO na isplaćeni iznos dužan vratiti kamate od dana podnošenja zahtjeva poslodavca za povrat uplaćenog iznosa.

Ovdje se otvara pitanje koji je iznos radnik dužan vratiti poslodavcu; ukupan bruto iznos koji je poslodavac isplatio u koji su uključene uplate na i iz plaće te porez i prirez ili sam iznos naknade plaće koji je radnik primio. Budući da je radnik u tom razdoblju (silom zakona) i dalje u radnom odnosu kod poslodavca, mišljenja samo da bi poslodavac imao pravo na povrat neto naknade plaće.

\subsection{Isplata na temelju pravomoćne presude}

U postupcima koji se vode radi utvrđenja nedopuštenosti otkaza ugovora o radu i nastavno na to isplate naknade plaće, ponekad se događa da pravomoćnu presudu kojom je otkaz utvrđen i naložena isplata naknade plaće, svojom odlukom Vrhovni sud Republike Hrvatske preinači tako da odbije tužbeni zahtjev radnika ili ukine pravomoćnu presudu.

U tim situacijama dolazi i do primjene instituta stjecanja bez osnove jer je došlo do prijelaza imovine poslodavca u imovinu radnika na temelju osnove koja je kasnije otpala (čl. 1111. st. 3. ZOO-a) pa je radnik kao stjecatelj dužan vratiti isplaćeno.

U skladu s čl. 1115. ZOO-a radnik je poslodavcu na isplaćene iznose dužan platiti i zatezne kamate koje teku od dana podnošenja zahtjeva poslodavca budući da radnik u vrijeme isplate na temelju pravomoćne presude nije bio nepošten stjecatelj.

\section{RAČUNANJE ROKOVA}

Budući da ZR ne uređuje pitanje računanja rokova, a da, kao što smo već istaknuli čl. 8. st. 4. ZR-a, upućuje na supsidijarnu primjenu ZOO-a, to se na temelju ove odredbe na računanje rokova u radnim odnosima odredbe ZOO-a. ${ }^{40}$

Čl. 300. st. 1. ZOO-a propisano je da se rokovi računaju na pune dane (computatio civilis), tako da rok određen u danima počinje teći prvog dana poslije događaja od kojeg se rok računa, a završava se istekom posljednjeg dana roka. Ako je npr. radnik primio odluku o otkazu ugovora o radu dana 1. travnja 2015., taj se dan neće računati u rok od 15 dana u kojemu roku radnik poslodavcu može podnijeti zahtjev za zaštitu prava. Rok za ulaganje zahtjeva za zaštitu prava počinje teći od 2. travnja i završava 16. travnja 2015.

U vezi s rokovima koji se određuju u tjednima, mjesecima ili godinama, oni po čl. 300. st. 2. Zakona o obveznim odnosima završavaju onoga dana koji se po imenu i broju podudara s danom nastanka događaja od kojega rok počinje teći. Ako takva dana nema u posljednjem mjesecu, kraj roka pada na posljednji dan toga mjeseca (za rokove određene u tjednima, mjesecima ili godinama ne važi pravilo da

40 Vrhovni sud, Revr 713/05-2 od 2. ožujka 2006. 
rok počinje teći prvog dana poslije događaja od kojeg se rok računa, budući da to važi samo za rokove određene u danima). ${ }^{41}$

Ako posljednji dan roka pada u dan kada je zakonom određeno da se ne radi, kao posljednji dan roka računa se sljedeći radni dan. ${ }^{42}$ Ovo pravilo važi za sve rokove, kako one koji su određeni u danima, tako i na rokove određene u tjednima, mjesecima i godinama. Kako se u nekim propisima ili ugovornim odnosima kao početak ili završetak roka navode pojmovi ,početak, sredina ili kraj mjeseca“, to je u čl. 300. st. 4. Zakona o obveznim odnosima navedeno što se pod tim pojmovima smatra. $^{43}$

Kako to konkretno izgleda u praksi, možemo vidjeti iz sljedeće odluke; „Sukladno spomenutoj odredbi ZR, ugovor o radu može se izvanredno otkazati samo u roku od 15 dana od dana saznanja za činjenicu na kojoj se izvanredni otkaz temelji. Rok u kojem se može izvanredno otkazati ugovor o radu je materijalnopravni, a ne procesnopravni rok, pa budući da računanje tog roka nije uređen Zakonom o radu, pitanje računanja istog ocjenjuje se primjenom općih propisa obveznog prava, a što proizlazi iz odredbe čl. 6. ZR kojom je određeno da se na sklapanje, valjanost, prestanak ili drugo pitanje u svezi s ugovorom o radu koje nije uređeno Zakonom o radu ili drugim zakonom, primjenjuju u skladu s naravi toga ugovora opći propisi obveznog prava. Sukladno tome, za računanje rokova iz čl. 114. st. 2. ZR mjerodavne su odredbe čl. 300. Zakona o obveznim odnosima ("Narodne novine" br. 35/05, 41/08 - dalje: ZOO). Prema odredbi čl. 300. st. 3. ZOO u slučaju ako posljednji dan roka pada u dan kada je zakonom određeno da se ne radi, kao posljednji dan roka računa se slijedeći radni dan. Zakonom o radu nedjelja je definirana kao neradni dan (čl. 46. ZR). Stoga, imajući na umu činjenična utvrđenja u postupku koji je prethodio reviziji, pravilan je zaključak nižestupanjskih sudova da je otkaz ugovora o radu tužitelju od 12. veljače 2007. dan u zakonom predviđenom roku od 15 dana od dana saznanja tuženika (27. siječnja 2007.) za činjenicu da je tužitelj koristio službeno vozilo u privatne svrhe kojom prilikom je pod utjecajem alkohola doživio prometnu nezgodu, budući da posljednji dan roka pada u dan kada je zakonom određeno da se ne radi (nedjelja 11. veljače 2007.), pa je sukladno odredbi čl. 300. ZOO koja je mjerodavna za računanje rokova, posljednji dan roka za izvanredno otkazivanje ugovora o radu tužitelju bio upravo 12. veljače 2007.“44

41 Terek, Darko; Računanje rokova, Računovodstvo i financije, br. 5/15.

42 Uobičajeno da je nedjelja dan u tjednu u kojem se ne radi . Osim nedjelje, ne radi se u dane blagdana koji su navedeni u čl. 1. Zakona o blagdanima, spomendanima i neradnim danima u Republici Hrvatskoj (Nararodne novine, br. 33/96 do 130/11). To su 1. siječnja - Nova godina, 6. siječnja - Bogojavljanje ili Sveta tri kralja, Uskrs i Uskrsni ponedjeljak, Tijelovo, 1. svibnja - Praznik rada, 22. lipnja - Dan antifašističke borbe, 25. lipnja - Dan državnosti, 5. kolovoza - Dan pobjede i domovinske zahvalnosti i Dan hrvatskih branitelja, 15. kolovoza Velika gospa, 8. listopada - Dan neovisnosti, 1. studenoga - Svi sveti, 25. prosinca - Božić i 26. prosinca, prvi dan po Božiću, Sveti Stjepan.

43 Terek, Darko; op.cit.

44 Vrhovni sud, Revr-1329/10 od 23.11.2010. 


\section{PRIMJENA ODREDBI ZOO-a KOD PRESTANKA UGOVORA $O R A D U$}

Iako se ZR zasniva na građanskopravnom pristupu, zakonodavac je ipak prestanak ugovora o radu normirao kogentnim odredbama, time ograničavajući prava ugovornih strana. Tako je odredbom čl. 112. ZR propisano osam načina prestanka ugovora o radu; smrću radnika; smrću poslodavca fizičke osobe ili prestankom obrta po sili zakona ili brisanjem trgovca pojedinca iz registra u skladu s posebnim propisima; istekom vremena na koje je sklopljen ugovor o radu na određeno vrijeme, kada radnik navrši 65 godina života i 15 godina mirovinskog staža, osim ako se poslodavac i radnik drukčije ne dogovore; sporazumom radnika i poslodavca; dostavom pravomoćnog rješenja o priznanju prava na invalidsku mirovinu zbog potpunog gubitka radne sposobnosti za rad, otkazom, odlukom nadležnog suda.

Radi se o taksativnom nabrajanju tako da ugovor o radu prema ZR-u može prestati samo na jedan od propisanih načina, a što je posljedica radi zaštite radnika kao slabije ugovorne strane. Budući da je riječ o kogentnim zakonskim odredbama koje normiraju specifični dio materije radnog prava, to je primjena odredbi ZOO-a u prvenstveno primjenjiva na prestanak ugovora o radu na temelju sporazuma radnika i poslodavca.

S obzirom na to da spominjemo prestanak ugovora o radu, istaknuti ćemo i situacije prestanka, odnosno otkaza menadžerskog ugovora jer se tad primjenjuju odredbe ZOO-a. Naime, čl. 4. st. 3. ZR-a određeno je da fizička osoba koja je prema propisu trgovačkog o trgovačkim društvima, kao član uprave ili izvršni direktor ili fizička osoba koja je u drugom svojstvu prema posebnom zakonu, pojedinačno i samostalno ili zajedno i skupno, ovlaštena voditi poslove poslodavca, može kao radnik u radnom odnosu obavljati određene poslove za poslodavca. Čl.4.st.4. ZR-a propisano je da se na osobu iz stavka 3. tog članka ne primjenjuju odredbe ZR-a o ugovoru o radu na određeno vrijeme, prestanku ugovora o radu, otkaznom roku i otpremnini.

Budući da se ne primjenjuju odredbe o prestanku ugovora o radu, tada se na otkaz tog ugovora primjenjuju odredbe ZOO-a. ${ }^{45}$ Mogućnost otkaza ugovora člana uprave društva na određeno vrijeme se ne podrazumijeva, već se mora posebno ugovoriti. Sloboda ugovaranja omoguće da ugovorne strane urede prestanak ugovora samim ugovorom što znači da mogu predvidjeti razloge za otkaz i trajanje otkaznih rokova. ${ }^{46}$

Ako ugovorne strane ne urede prestanak ugovora, trebalo bi primijeniti odredbe čl. 211. i čl. 212. ZOO-a. Naime, čl. 211. ZOO-a je određeno da trajni

45 S članom uprave d.d. sklapa se ugovor na određeno vrijeme (arg. iz čl. 244. st. 1. Zakona o trgovačkim društvima), dok je s članom uprave d.o.o.-a moguće sklopiti i ugovor bez vremenskog ograničenja (arg. iz čl.423. i 424 ZTD).

46 Gregurev, Ivana; Pravna priroda i sadržaj menadžerskih ugovora, Radno pravo, Zagreb, 2011., str. 122. 
obvezni odnos s određenim rokom trajanja prestaje kad rok istekne, osim kad je ugovoreno ili zakonom određeno da se poslije isteka roka obvezni odnos produljuje za neodređeno vrijeme, ako ne bude pravodobno otkazan. Prema čl. 212. ZOO-a, "(1) ako trajanje obveznog odnosa nije određeno, svaka ga strana može okončati otkazom. (2) Otkaz mora biti dostavljen drugoj strani. (3) Otkaz se može dati u svako doba, samo ne u nevrijeme. (4) Otkazani obvezni odnos prestaje kad istekne otkazani rok određen ugovorom, a ako takav rok nije određen ugovorom, odnos prestaje nakon isteka roka određenog zakonom ili običajem, odnosno istekom primjerenog roka. (5) Strane mogu ugovoriti da će njihov obvezni odnos prestati samom dostavom otkaza, ako za određeni slučaj zakon ne naređuje što drugo. (6) Vjerovnik ima pravo zahtijevati od dužnika ono što je dospjelo prije nego što je obveza prestala protekom roka ili otkazom."

U slučaju izostanka ugovornog uređenja prestanka menadžerskog ugovora člana uprave, citirane odredbe o trajnom obveznom odnosu ne daju precizne odgovore o primjerenom otkaznom roku. Stoga bi dopune navedenih odredbi ZOO-a bile potrebne radi postizanja pravne sigurnosti. ${ }^{47}$

\subsection{Sporazum poslodavca i radnika o prestanku ugovora o radu}

Sporazum predstavlja suglasnu volju radnika i poslodavca za prestankom ugovora o radu. On je rezultat njihove slobodne volje pa stoga odbijanje radnika za sklapanjem takvog sporazuma ne smije imati negativne posljedice na njegov radnopravni status. ${ }^{48}$

Čl. 113. ZR-a propisano je da sporazum o prestanku ugovora o radu mora biti zaključen u pisanom obliku iz čega proizlazi da zakonodavac propisuje stroži odnos prema formi sporazuma o prestanku ugovora o radu, nego o formi samog ugovora o radu. ${ }^{49}$

U sudskoj praksi se ističe da je ta odredba prisilne (kogentne) naravi i da usmeni dogovor o sporazumnom prestanku ugovora o radu ne može obvezivati sudionike, kada je izričito propisan pisani oblik sporazuma o prestanku ugovora o radu..$^{50}$ Pisani oblik sporazuma onemogućuje da se o sporazumu stranaka zaključuje na temelju njihovih konkludentnih radnji. Primjerice da ponudu poslodavca za sklapanje ugovora o prestanku ugovora o radu radnik prihvati vraćanjem ključeva službenih prostorija i prestankom dolaženja na posao. ${ }^{51}$ Sam sporazum ne mora

47 Gregurov, Ivana, op. cit. str.122.

48 Sama činjenica da je radnik odbio potpisati sporazum ne može predstavljati razlog za otkaz ŽS u Karlovcu br. Gž -237/99 od 7.4.1999.

49 „Usmeni dogovor o sporazumnom prestanku ugovora o radu ne može obvezivati sudionike, kada je izričito propisan pisani oblik sporazuma o prestanku ugovora o radu." Vrhovni sud, Revr-300/09 od 3.9.2009.

50 ŽS u Zagreb u br. Gž-2539/97 od 11. 11. 1997.

51 Potočnjak, Željko. Prestanak ugovora o radu, u: Crnić, Ivica et al. Radni odnosi u Republici Hrvatskoj. Zagreb: Pravni fakultet u Zagrebu i Organizator, 2007., str. 378. Autor navodi da se u njemačkom radnom pravu može o pristanku radnika na ugovor (sporazum) o prestanku ugovora o radu zaključivati i na temelju njegova ponašanja. 
biti u obliku jednog dokumenta potpisanog od obje ugovorne strane. ${ }^{52}$ Naime, kada radnik dostavi pisanu ponudu poslodavcu u kojem predlaže sporazumni prestanak radnog odnosa, a poslodavac istu prihvati donošenjem odluke koju odmah dostavi radniku, tada je u smislu čl. 252. st. 1. ZOO-a zaključen ugovor o sporazumnom prestanku radnog odnosa. ${ }^{53}$ Takvo pravno shvaćanje nailazimo u niz odluka;““ Zakonom o radu propisana je samo pisana forma tog ugovora, pa se s obzirom na odredbu čl. 6. ZR-a na ostala pitanja u svezi sporazuma o prestanku ugovora o radu primjenjuju opći propisi obveznog prava. Taj sporazum, jednako kao i svaki drugi dvostrani pravni posao je sklopljenog onog časa kad ponudilac (u konkretnom slučaju tužiteljica) primi izjavu ponuđenog da prihvaća ponudu (čl. 31. st. 1. ZOO). Svoju ponudu za sklapanje ugovora o prestanku ugovora o radu tužiteljica je dala u pisanom obliku propisanom za sklapanje tog ugovora, pa budući da je tu ponudu tuženica prihvatila pobijanom odlukom o prestanku ugovora o radu od 3. listopada 2002., sudovi su pravilno primijenili materijalno pravo kada su zaključili da je do prestanka ugovora o radu došlo sporazumom, te da stoga pobijana odluka nema značenje otkaza ugovora o radu i kada su slijedom toga tužbeni zahtjev ocijenili neosnovanim. ." 54

U praksi su česte situacije da poslodavac jednostavno na prijedlog radnika za sporazumnim prestankom naznači svoj pristanak uz potpis, što se također smatra sklopljenim sporazumom..$^{55}$

Budući da sporazum predstavlja dvostrani pravni akt koji se temelji na volji ugovornih strana, niti jedna od ugovornih strana nije ovlaštena jednostrano ga mijenjati. ${ }^{56}$

Sporazumom bi stranke trebale u cijelosti urediti sva pitanja koja proizlaze iz njihova ugovornog (radnog) odnosa, počevši od dana prestanka ugovora o radu, pitanja otkaznog roka, novčanog dospjelog potraživanja i sl. Premda ZR ne priznaje pravo na otpremninu ako radni odnos prestaje sporazumom, ${ }^{57}$ stranke mogu

52 „Tužitelj je predao upravi tuženika molbu za sporazumni prestanak ugovora o radu koju je osobno potpisao 5. travnja 2005., a tuženik je prihvatio molbu i u pisanom obliku odlučio o prestanku tužiteljevog ugovora o radu sklopljenog na neodređeno vrijeme 1. listopada 1984. Time su radnik i poslodavac kao stranke ugovornog odnosa izrazile suglasnu volju za prestanak radnogodnosa i to baš u obliku propisanom odredbom čl. 104. ZR." Vrhovni sud, Revr-277/13 od 16.9.2014.

53 Tako i Milković, Darko, Sklapanje i prestanak ugovora o radu. u: Crnić, Ivica et al. Aktualna pitanja ostvarivanja i zaštite prava iz radnih odnosa. Zagreb: Inženjerski biro, 2007., str. 112.

54 Vrhovni sud, Revr 469/08-2 od 25.2.2009.

55 „S obzirom da je tužiteljica 1. travnja 2008. predala zahtjev za sporazumni raskid ugovora o radu s danom 30. travnja 2008. neposredno na ruke direktorici tuženika i da je direktorica tuženika istog trenutka prihvatila taj zahtjev tako što je rekla „u redu“ i na zahtjev stavila svoj potpis i pečat tuženika i prema shvaćanju ovog revizijskog suda u tom trenutku je sklopljen sporazum o prestanku ugovora o radu u svemu prema zahtjevu tužiteljice." Vrhovni sud, Revr-518/11 od 8.9.2012.

56 VSRH Rev 1839/99 od 6.2.2001.

57 VSRH Rev 2876/98 od 27.6. 2002. VSRH Rev 3372/99 od 27.11.2001. «Kad je radnik istovremeno prihvatio ponudu navedenu u odluci o otkazu ugovora o radu da sukladno Programu rješavanja viška radnika nastavi s radom kod drugog poslodavca, ne pripada mu pravo na otpremninu u smislu čl. 118. ZR « 
ugovoriti i isplatu otpremnine, $\mathrm{i}$ to $\mathrm{u}$ većem iznosu nego je to zakonom propisano. ${ }^{58}$

Poslodavac i radnik mogu zaključiti sporazum o prestanku ugovora o radu i ako je poslodavac donio odluku o otkazu (a radni odnos po njoj još nije prestao), te će u tom slučaju temelj za prestanak ugovora o radu biti sporazum stranaka. ${ }^{59}$ Ako sporazumom o prestanku ugovora o radu, odluka o otkazu ugovora o radu nije izrijekom stavljena izvan snage, prema pravnom shvaćanju sudske prakse smatra se da je poslodavac tu odluku prešutno stavio izvan snage. ${ }^{60}$

Ako neka od strana smatra da sporazum nije valjan, morao bi u postupku tražiti njegovo poništenje ili utvrđenje ništetnosti. „Prema odredbi čl. 103. točka 5. ZR ugovori o radu mogu uz ostale razloge prestati sporazumom između poslodavca i zaposlenika. Takav sporazum je pravni posao građanskog prava, pa u odnosu na njegovu valjanost vrijede opća pravila obveznog prava iz ZOO-a. Sudovi su ocijenili da je tužitelju bilo poznato pod kojim uvjetima mu prestaje radni odnos, da je potpisom Sporazuma pristao na takve uvjete te da Sporazum nije ni ništetan ni pobojan i obvezuje obje ugovorne strane onako kako glasi. Stoga Sporazum proizvodi pravne učinke između ugovornih strana, pa je radni odnos tužitelja prestao na valjan način zbog razloga iz čl. 103. ZR-a, a tužitelj nema pravo na poticajnu otpremninu pa je tužbeni zahtjev za utvrđenjem ništavim i za poništaj Sporazuma odbijen pravilnom primjenom materijalnog prava." Vrhovni sud, Revr-110/10 od 27.6.2013.

Ako između stranaka bude sporno tumačenje sadržaja sporazuma o prestanku ugovora o radu i to naročito stoga što se stranke ne slažu po pitanju eventualnog (neriješenog) materijalnog potraživanja, tad će sudovi u skladu s odredbama ZOO-a, istražiti zajedničku namjeru ugovaratelja i odredbu tako razumjeti kako to odgovara načelima obveznog prava. ${ }^{61}$

Relativno su česte situacije u kojima su stranke sklopile sporazum o prestanku ugovora o radu, ali je poslodavac uz to donio i odluku o otkazu ugovora o radu. $\mathrm{U}$ situaciji kad je sud zaključio da otkaz nije zakonit, tad se smatra da je sam sporazum

58 VSRH Rev-2385/97 od 4.2.1998. Inače, prema odredbi čl. 118. st. 2. ZR otpremnina se ne smije ugovoriti, odnosno odrediti u iznosu manjem od jedne trećine prosječne mjesečne plaće, koju je radnik ostvario u tri mjeseca prije prestanka ugovora o radu, za svaku navršenu godinu rada kod tog poslodavca.

59 VSRH Rev-2387/97 od 4.2.1998.

60 VS RH Rev-2876/98 od 27.6.2002.

61 „Stoga obzirom na sve utvrđene okolnosti prilikom zaključenja Sporazuma o prestanku ugovora o radu od 12. rujna 1997., odredba čl. 5. navedenog Sporazuma može se tumačiti kao izraz prave volje stranaka odnosno zajedničke namjere ugovaratelja da "jedna prema drugoj nemaju nikakvih potraživanja" odnosno dugova, budući je to jedini smisao čl. 5. Sporazuma. Kako su sudovi nižeg stupnja pravilno ocijenili pravu volju stranaka, kako tužitelja tako i tuženika ugovorenu u odredbi čl. 5. citiranog Sporazuma, to su pravilno primijenili materijalno pravo odredbe čl. 6. Zakona o radu (Narodne novine, br. 38/95., 54/95., 65/95., 17/01., 82/01., 114/03. i 30/04. u vezi s čl. 99. i čl. 344. Zakona o obveznim odnosima "Narodne novine”, broj 53/91., 73/91., 3/94., 7/96., 91/96., 112/99. i 88/01.).“ Vrhovni sud, Revr 406/06-2 od 6.2.2008. 
i dalje na snazi između stranaka primjenjujući pritom odredbe ZOO-a o raskidu ugovora i održanju ugovora na snazi. ${ }^{62}$

\section{ODGOVORNOST ZA ŠTETU NASTALU U IZVRŠENJU UGOVORA O RADU}

\subsection{Odgovornost radnika za štetu uzrokovanu poslodavcu}

Da bi radnik odgovarao za štetu uzrokovanu poslodavcu, potrebno je ispuniti pretpostavke propisane u čl. 107. st. 1. ZR a to su; da je šteta prouzročena na radu, odnosno u svezi s radom; da je šteta nastala namjerno ili zbog krajnje nepažnje te da je poslodavcu nastala šteta.

Radnikova je temeljna obveza, obaviti preuzeti posao u skladu s prema uputama poslodavca danim u skladu s naravi i vrstom rada (čl.7.st.1.ZR-a). Ako pri izvršenju poslova koji predstavljaju izvršavanje obveza iz radnog (ugovornog) odnosa nastane šteta, ta se šteta smatra štetom na radu. Također, ako je radnik štetu počinio za vrijeme aktivnosti koje ne predstavljaju redovito obavljanje poslova i radnih zadataka, ali predstavljaju obvezu iz radnog odnosa, tad se nastala šteta smatra štetom u svezi s radom. Radi se o situaciji kada radnik počini štetu pri obavljanju poslova koje mu je naložio rukovoditelj, a premda ih je prema ugovoru o radu dužan izvršiti, do tada ih nije ne obavljao redovito. Nadalje, ovdje bi mogli svrstati i one štete koje radnik nanese poslodavcu za vrijeme dnevnog odmora jer ta vrsta odmora ulazi u sastavni dio procesa rada.

Potrebno je istaknuti da se ovom odredbom isključivo regulira situacija kada štetu skrive radnici koji su u radnom odnosu kod poslodavca. Za štetu koju, primjerice, učini radnik privremeno zaposlen na temelju sporazuma sklopljenog

62 „Prije svega, treba reći da pogrešno drugostupanjski sud smatra da je sporazum o prestanku ugovora o radu prestao samom činjenicom da je nakon sklapanja tog sporazuma tuženik donio odluku o otkazu ugovora o radu, a to upravo zbog toga što je otkaz utvrđen nedopuštenim. $\mathrm{S}$ obzirom da je navedeni otkaz ugovora o radu utvrđen nedopuštenim tada takva odluka tuženika o otkazu ne proizvodi nikakav pravni učinak - ni na prestanak ugovora o radu niti na prestanak sporazuma o prestanku ugovora o radu. Kad nakon sklapanja sporazuma o prestanku ugovora o radu poslodavac da otkaz radniku, a otkaz tog ugovora bude utvrđen nedopuštenim tada takva odluka nije od utjecaja na taj sporazum i sama po sebi ne uzrokuje prestanak tog sporazuma ili prestanak ugovora o radu. Pogrešno smatra i prvostupanjski sud da je u konkretnom slučaju sporazum između stranaka o prestanku ugovora o radu prestao po samom zakonu u smislu čl. 125. st. 1. ZOO. Naime, prema odredbi čl. 125. st. 2. ZOO u slučaju raskida po samom zakonu iz čl. 125. st. 1. ZOO vjerovnik može održati ugovor na snazi ako nakon isteka roka, bez odgađanja,obavijesti dužnika da zahtijeva ispunjenje ugovora. U konkretnom slučaju tužitelj je u tužbi izričito naveo da je donošenjem odluke o izvanrednom otkazu ugovora o radu izražena namjera tuženika da prekrši odredbe sporazuma o prestanku ugovora o radu, a da tužitelj smatra da je prava volja stranaka izražena tim sporazumom i da se sporazum ne može raskinuti kako to čini tuženik jednostrano. Na taj način je tužitelj postupio upravo u skladu s odredbom čl. 125. st. 2. ZOO, pa je time sporazum o prestanku ugovora o radu održan na snazi." Vrhovni sud, Revr 619/05-2 24.1.2006. 
između poslodavca i agencije za privremeno zapošljavanje, poslodavcu ne odgovara radnik već u skladu sa čl. 51. st. 2. ZR-a odgovara agencija prema općim propisima obveznog prava.

Radnik odgovara za štetu uzrokovanu poslodavcu koju počini na radu odnosno u vezi s radom samo ako ju je počinio namjerno ili s krajnjom nepažnjom. Namjera je najteži oblik krivnje a određuje se subjektivno. Prema pravnoj teoriji, namjera je takva vrsta krivnje kod koje se traži da je štetnik postupao znajući i hotimice (to znači da se kod namjere traži i volja i znanje). ${ }^{63}$ To znači da je radnik svjestan da će svojom radnjom ili propuštanjem izazvati štetu. S krajnjom nepažnjom ili grubom nemarnošću postupa onaj radnik koji u svom radu ne upotrijebi ni onu pažnju koju bi upotrijebio prosječni čovjek (radnik).

Ako je radnik štetu poslodavcu počinio s običnom nepažnjom on za štetu ne odgovara. S tim u vezi posebno ističemo da se prema općim pravilima krivnja štetnika ne predmnijeva, odnosno da se predmnijeva obična nepažnja, dok namjeru ili nepažnju štetnika mora dokazivati oštećenik ${ }^{64}$ To znači da će se u postupku koji poslodavac pokrene protiv radnika radi naknade štete koju mu je on prouzrokovao na radu, odnosno u svezi s radom podrazumijevati da je radnik štetu počinio uslijed obične nepažnje sve dok poslodavac ne dokaže veći stupanj krivnje; namjeru ili nepažnju radnika. Tek kad poslodavac to dokaže, ako su ispunjeni ostali uvjeti, poslodavac ima pravo na naknadu štete. Uz to, mora postojati i pravno relevantna uzročna veza između radnje radnika (ili propuštanja) i nastale štete.

Pod štetom se, najkraće rečeno, podrazumijeva promjena nekog stanja nagore. Šteta koju poslodavac pretrpi može biti imovinska i neimovinska šteta. Naime, prema čl. 1046. ZOO-a šteta je umanjenje nečije imovine (obična šteta) i sprječavanje njezina povećanja (izmakla korist) i to su s jedne strane imovinska šteta, dok s druge imamo povredu prava osobnosti kao neimovinsku šteta (to je prema čl. 19. st. 2. ZOO-a primjerice pravo na život, tjelesno i duševno zdravlje, ugled, čast, dostojanstvo, ime, privatnost osobnog i obiteljskog života, slobodu i dr.).

S tim u vezi, potrebno je istaknuti da je ZOO izjednačio fizičke i pravne osobe u pravu na naknadu neimovinske štete (čl. 19.) te izričito priznaje i pravnim osobama pravo na neimovinsku štetu. Stoga i poslodavac kao pravna osoba ima pravo na popravljanje neimovinske štete kako u nenovčanom, tako i u novčanom obliku. Naime, pravna osoba (čl. 19. st. 3. ZOO-a) ima sva prava osobnosti kao i fizička osoba što se posebno odnosi na pravo na ugled i dobar glas, čast, ime odnosno tvrtku, poslovnu tajnu, slobodu privređivanja i drugo (razlika je jedino u pravu osobnosti vezanih uz biološku bit fizičke osobe). ${ }^{65}$ Ukratko, pravna osoba prema čl. 19. st. $3 . Z O O$ ima pravo na sljedeća prava osobnosti; ugled, dobar glas i čast, ime odnosno tvrtku, poslovnu tajnu, slobodu privređivanja i druga prava.

63 Vedriš- Klarić Osnove imovinskog prava, str.209.

64 Čl. 1045. st. 2. ZOO.

65 Tako i Crnić, Ivica Povreda prava osobnosti kao neimovinska šteta, u Barbić. J. et al., Odgovornost za štetu, Inženjerski biro d.d. Zagreb, ožujak 2006., str. 56. 
Budući da poslodavac može biti i fizička osoba (obrtnik) napominjemo da se pod pravom osobnosti fizičke osobe u smislu čl. 19. st. 2. ZOO-a se razumijeva; život, tjelesno zdravlje, duševno zdravlje, ugled, čast, dostojanstvo i ime, privatnost osobnog i obiteljskog života, slobodu i druga prava.

Ako štetu uzrokuje više radnika, svaki radnik odgovara za dio štete koji je uzrokovao (čl. 107. st. 2. ZR-a). Ovom je odredbom propisana podijeljena odgovornosti radnika za štetu koju uzrokuju poslodavcu. Time je napravljen izuzetak od općeg pravila obveznog prava prema kojem kada više osoba odgovara za štetu one odgovaraju solidarno (čl. 1107. ZOO-a). Međutim, ako nije moguće utvrditi koliki je udio svakog od radnika u prouzročenju štete, tad su svi radnici podjednako odgovorni i štetu naknađuju u jednakim dijelovima (čl.107.st.3.ZR-a).

Solidarna odgovornost koja odgovara pravilima obveznog prava, predviđena je jedino u slučaju ako je više radnika uzrokovalo štetu kaznenim djelom počinjenim $\mathrm{s}$ namjerom (čl.107.st.4.ZR-a). U tom slučaju poslodavac može birati hoće li naknadu štete potraživati od svih radnika ili od pojedinog radnika koji odgovara poslodavcu za čitavu štetu. ${ }^{66}$ Radnik koji je platio čitavu štetu poslodavcu, može od drugih radnika zahtijevati da mu naknade ono što je platio za njih.

\subsection{Regresna odgovornost radnika}

Odredba čl. 109. ZR-a regulira pravo poslodavca na regres kad je radnik trećoj osobi uzrokovao štetu, a naknadio ju je poslodavac. Iz odredbe proizlazi da regresna odgovornost radnika postoji u slučaju kad je radnik na radu ili u svezi s radom trećoj osobi počinio štetu, kad je radnik štetu uzrokovao namjerno ili zbog krajnje nepažnje te kad je štetu koja je nastala trećoj osobi, naknadio poslodavac.

Ako su ispunjene navedene pretpostavke, radnik je obvezan poslodavcu naknaditi iznos koji je radi naknade štete poslodavac isplatio trećoj osobi. ${ }^{67}$ Poslodavac regres od radnika može zatražiti od dana kad je trećoj osobi naknadio štetu. Istovremeno, on može potraživati i zateznu kamatu na isplaćenu glavnicu tekuću od dana isplate trećoj osobi.

U kojem roku zastarijeva pravo poslodavca da od radnika potražuje isplatu naknađene štete? Budući da ZR to pitanje ne uređuje, u skladu sa čl. 8. st. 4. ZR-a primjenjuju se opća pravila obveznog prava. Čl. 1061. st. 1. ZOO-a propisano je da poslodavac odgovara za štetu koju zaposlenik u radu ili u svezi s radom prouzroči trećoj osobi osim ako dokaže da su postojali razlozi koji isključuju odgovornost zaposlenika. St.3. tog članka propisano je da poslodavac koji je oštećeniku popravio štetu ima pravo zahtijevati od zaposlenika naknadu troškova popravljanja štete, ako je ovaj štetu prouzročio namjerno ili iz krajnje nepažnje, dok je st. 4. propisano da

66 Solidarni dužnici su obični suparničari, tako da poslodavac svojom tužbom za naknadom štete nije dužan obuhvatiti sve radnike koji su počinili štetu.

67 „Poslodavac može osnovano od radnika zahtijevati vraćanje iznosa isplaćenog trećoj osobi s naslova naknade štete koju je radnik prouzročio na radu ili u vezi s radom ako je štetu prouzročio namjerno ili iz krajnje nepažnje." Vrhovni sud, Rev-1846/87 od 28.1.1988. 
to pravo zastarijeva u roku od šest mjeseci od dana kad je šteta popravljena. Dakle, poslodavčevo pravo na regresno potraživanje od radnika zastarijeva u roku od šest mjeseci od dana kad je šteta popravljena odnosno od dana kad je poslodavac trećoj osobi popravio štetu ili je novčanim iznosom naknadio. Dakle, ZOO je za razliku od ZR-a gdje bi bilo logičnije da je uređena ta materija, propisao rok u kojem poslodavac može regresno potraživanje zatražiti od radnika.

\subsection{Odgovornost poslodavca za štetu uzrokovanu radniku ${ }^{68}$}

Čl. 110. ZR-a propisana je odgovornost poslodavca za štetu uzrokovanu radniku tako da je određeno da za štetu koju radnik pretrpi u radu ili u svezi s radom, poslodavac je radniku dužan naknaditi prema općim propisima obveznog prava ${ }^{69}$ Međutim, koje ćemo odredbe ZOO-a primjenjivati, ovisit će o činjenici je li šteta nastala kao posljedica skrivljenog ponašanja ili djelovanja opasne stvari odnosno opasne djelatnosti. Dakle, odgovornost se može temeljiti na presumiranoj krivnji ili na objektivnom kriteriju uzročnosti.

Kad poslodavac odgovara prema kriteriju krivnje, on odgovara po predmnijevanoj (presumiranoj) krivnji (čl. 1045. st.1. i 2. ZOO-a). Predmnijeva se najblaži oblik krivnje. obična nepažnja (culpa levis). Na poslodavcu je teret dokaza da je šteta nastala bez njegove krivnje. Više stupnjeve krivnje - krajnju nepažnju ili namjeru radnik mora dokazati poslodavcu, tj. tada je teret dokaza na radniku. ${ }^{70}$ Napominjemo da je čl. 1045. st .1. ZOO propisano da tko drugome prouzroči štetu, dužan je naknaditi ako ne dokaže da je šteta nastala bez njegove krivnje.

U slučaju da radnik na radu ili u svezi s radom strada od stroja ili predmeta koji imaju obilježja opasne stvari, odnosno kad strada za vrijeme obavljanja djelatnosti koja ima obilježja opasne djelatnosti, pri utvrđivanju odgovornosti

68 Više o odgovornosti poslodavca za naknadu štete radniku vidjeti kod: Crnić, Ivica Odgovornost za štetu iz radnog odnosa u Crnić I. et al. Aktualnosti i novine u radni odnosima i zdravstvenom osiguranju, Novi informator 2009., str. 65-92., Crnić, Ivica Povreda prava osobnosti i naknada neimovinske štete u radnim odnosima u Crnić, I. et. al. Aktualna pitanja ostvarivanja i zaštite prava iz radnih odnosa, Inženjerski biro d.d. 2007., str. 64-94.; Frntić, Domagoj Franjo Odgovornost poslodavca prema radniku za štete nastale slučajem uslijed ozljede na radu, profesionalne bolesti ili bolesti u vezi rada Radno pravo, 2/07, 8-10.; Nikšić, Saša Nekoliko napomena o odgovornosti za štetu u radnom pravu, Radno pravo, 2/07, str. 3-7.: Šojat Jasenka, Neka pitanja u vezi naknade štete koju radnik pretrpi na rad i u svezi s radom, Radno pravo 10/05., str. 13.-19.

69 „Tuženik se ne može osloboditi odštetne odgovornosti pozivajući se na protupravno djelovanje treće osobe koji iako nije bio radnik tuženika, fizički je nasrnuo na tužitelja kada je tužitelj po nalogu istovarivao robu iz svog kamiona, jer u konkretnom slučaju nema svojstvo treće osobe u smislu Zakona o zaštiti na radu, budući da tužitelj pri obavljanju poslova organizacije utovara robe u tvorničkom krugu tuženika, po redovnom tijeku stvari dolazi u kontakt s autoprijevoznicima koji nisu radnici tuženika, a koji su dolazili po robu." Vrhovni sud, Revr-348/12 od 22. 10. 2013.

70 Crnić, Ivica Naknada štete, u Babić, V. et al. Veliki komentar novog Zakona o radu, Vaša knjiga, Zagreb, 2010., str.161. 
poslodavca primjenjivati će se kriterij objektivne odgovornosti. Prema tom kriteriju poslodavac će odgovarati za štetu jer je zbog određenih radnji ili propusta došlo do štete, neovisno o tome postoji li krivnja poslodavca. ${ }^{71}$

Dakle, činjenica da na strani poslodavca nema propusta ili činjenja koji bi bili u uzročnoj vezi s povredom koju je pretrpio radnik na radu ili u vezi s radom, nije osnova za isključenje odgovornosti za štetu koju trpi povrijeđeni radnik. S tim u vezi, ističemo da je člankom 1063. ZOO-a propisano da šteta nastala u svezi s opasnom stari odnosno opasnom djelatnošću smatra se da potječe od te stvari odnosno djelatnosti, osim ako se dokaže da one nisu bile uzrok štete.

Pojam opasne stvari nije određen ZOO-om. Sudska praksa i pravna teorija je, međutim, definirala taj pojam, pa se opasnom stvari smatra ona pokretna ili nepokretna stvar čiji položaj, ili upotreba, ili osobina, ili samo postojanje, predstavlja povećanu opasnost nastanka štete za okolinu, tako da ih treba nadzirati povećanom pažnjom. ${ }^{72}$

Kao opasnu stvar kroz sudsku praksu smo susretali transportnu traku u pogonu, tokarski stroj s ugrađenim cirkularnom pilom u pokretu, dizalica, uključenu motornu pilu i sl. Za štetu nastalu od opasne stvari odgovara njen imatelj. ${ }^{73}$

Ni pojam opasne djelatnosti nije sadržajno određen propisima obveznog prava, već njegov sadržaj također valja potražiti u pravnoj teoriji i sudskoj praksi. Tako se neka djelatnost smatra opasnom samo onda kad u njezinom redovitom tijeku, već prema samo njezinoj tehničkoj prirodi i načinu obavljanja, može biti ugroženo zdravlje ljudi ili imovina, tako da to ugrožavanje zahtijeva povećanu pozornost osoba koje tu djelatnost obavljaju. ${ }^{74} \mathrm{U}$ sudskoj je praksi kao opasna djelatnost ocijenjeno da bi to bilo obaranje stabla motornom pilom, rad u rudniku, rad na platformi utovarivača, rad na visini, obavljanje poslova kontrolora karata u javnom prometu i sl. ${ }^{75}$

Potrebno je istaknuti da odgovornost poslodavca za štetu uzrokovanu ozljedom na radu, profesionalnom bolešću ili bolešću u svezi s radom uređuje i Zakon o zaštiti na radu. ${ }^{76}$

71 Čl. 1045. st. 3. ZOO.

72 Ova definicija odnosno pravno shvaćanje je zauzeto na Sjednici svih sudaca Suda udruženog rada Hrvatske od 8.4.1981.

73 „Dizalica izvan pogona, u stanju mirovanja, neovisno o njezinim dimenzijama, nije sama po sebi opasna stvar." Vrhovni sud, Rev x 31/11 od 31.1.2012.

74 Crnić, I., op. cit. str.162.

75 „U konkretnom slučaju, rad je tužitelj (električar kod tuženika) izvodio na skeli koja je bila postavlja na visini od $3,35 \mathrm{~m}$ bez zaštitne ograde, zbog čega se takav rad ima okarakterizirati kao opasna djelatnost. U situaciji kad je utvrđeno da je tuženik znao da postoji opasnost rada na skeli koja nema zaštitnu ogradu, pa je mogao predvidjeti da bi moglo doći do pad i teških posljedica a nije poduzeo radnje da to spriječi, bilo postavljanjem zaštitne ograde, ili pak sprječavanjem tužitelja da radi na takvoj skeli, ne može se očekivati od tužitelja da snosi dio odgovornosti s time što nije odbio izvršiti rad koji je po nalogu svog poslodavca obavljao." Vrhovni sud, Revr-839/07 od 3.2.2009.

76 Zakon o zaštiti na radu, Narodne novine, br.71/14., stupio je na snagu 19. lipnja 2014. 
Čl. 25. st. 1. toga Zakona propisano je da se ozljeda na radu i profesionalna bolest koju je radnik pretrpio obavljajući poslove za poslodavca smatra da potječe od rada i poslodavac za nju odgovara po načelu objektivne odgovornosti (prema st. 2. poslodavac može biti oslobođen odgovornosti ili se njegova odgovornost može umanjiti ako je šteta nastala zbog više sile, odnosno namjerom ili krajnjom nepažnjom radnika ili treće osobe, na koje poslodavac nije mogao utjecati niti je njihove posljedice mogao izbjeći, unatoč provedenoj zaštiti na radu). Premda se na prvi pogled čini da je time odgovornost u cijelosti izjednačena s odredbama ZOO-a, ovom se odredbom radnici ipak stavljaju u povoljniji položaj nego prema odredbama ZOO-a. Naime, u čl. 25. st. 1. Zakona o zaštiti na radu ugrađena je presumpcija prema kojoj se ozljeda na radu i profesionalna bolest koju je radnik pretrpio obavljajući poslove za poslodavca smatra da potječe od rada. To znači da će za svaku ozljedu koju radnik pretrpi na radu poslodavac morati dokazivati da postoje okolnosti iz st. 2., koje ga oslobađaju od odgovornosti. Do sad je poslodavac postojanje tih okolnosti dokazivao samo na situacije kad su u pitanju opasna stvar ili opasna djelatnost. Sad se to odnosi na sve ozljede koje radnik pretrpi obavljajući posao (primjerice, radnik u uredu padne preko kabla koji spaja računalo s printerom. Tu se ne bi radilo o opasnoj djelatnosti niti o opasnoj djelatnosti, ali zbog navedene odredbe poslodavac će se moći osloboditi odgovornosti jedino pod uvjetima koji smo naveli). Dakle, novim je Zakonom o zaštiti na radu teret dokazivanja u postupcima za naknadu štete koju je radnik pretrpio obavljajući poslove za poslodavca, u cijelosti prebačen na poslodavca. To bi se moglo odnositi čak i na situacije kad radnik nije dobio nalog da obavi neki posao, već je to išao napraviti samoincijativno. Obzirom da je obavljao posao za poslodavca, smatra se da šteta potječe od rada i poslodavac za nju odgovara po načelu objektivne odgovornosti.

Poslodavac odgovara radniku za naknadu uzrokovane štete i to i za imovinsku i za neimovinsku štetu. ZOO sadržava odredbe o načinu popravljanja imovinske (čl.1085. do 1098.) i neimovinske štete (čl. 1099. do 1106. ZOO-a). Posebno ističemo da ZOO u čl. 1046. neimovinsku štetu određuje kao povredu prava osobnosti. To znači da svakom povredom prava osobnosti nastaje neimovinska šteta. Međutim, to istovremeno ne znači da će radnik uvijek i bezuvjetno imati pravo na popravljanje štete i na isplatu pravične novčane naknade kao jednog od oblika popravljanja štete. To će pravo radnik ostvariti samo ako sud nađe da težina i okolnosti slučaja to opravdavaju.

Vidjeli smo da je st. 2. čl. 103. ZR-a propisano da pravo na naknadu štete iz st. 1. se odnosi i na štetu koju je poslodavac uzrokovao radniku povredom njegovih prava iz radnog odnosa. Radnik dakle, ima pravo na naknadu štete koja mu je nastala povredom njegovih prava iz radnog odnosa. To se može odnositi i na imovinsku i na neimovinsku štetu time da su do sada u praksi najčešće bili zastupljeni slučajevi naknade imovinske štete. Primjerice, kad je zbog poslodavčeve nezakonite odluke radniku uskraćeno pravo na jubilarnu nagradu, regres za godišnji odmor i sl. 


\section{ZAKLJUČ $A K$}

Kao što je iz rada vidljivo, široka primjena odredbi ZOO-a kod rješavanja pojedinih pitanja u vezi s ugovorom o radu, nije prisutna samo jer što je radni odnos ugovorni odnos, već i zbog toga što što ZR upućuje na supsidijarnu primjenu odredbi obveznog prava kod sklapanja, valjanosti, prestanka i drugih pitanja u vezi s ugovorom o radu, a koje nije uređeno tim ili drugim zakonom. Budući da je radni odnos ugovorni odnos, logično je da se na situacije sklapanja, promjene i prestanka ugovora na temelju suglasnih volja ugovornih strana, primjenjuju odgovarajuće odredbe ZOO-a.

Pored toga, ZR kod pojedinih instituta kao što je, primjerice pitanje odgovornost za štetu, izravno upućuje na pravila obveznog prava.

Pravila ZOO-a u vezi s ugovorom o radu primjenjujemo i pri računanju rokova koje propisuje ZR jer taj Zakon svojim odredbama ne regulirala računanje rokova. Primjenjuje se i institut stjecanja bez osnove kad je jedna od ugovornih strana stekla imovini druge, a taj prijelaz nema osnove u nekom pravnom poslu, odluci suda ili zakonu ili kad je ta osnova kasnije otpala.

Premda smo se u ovom radu bavili isključivo ugovorom o radu i ZOO-om, napominjemo da se odredbe tog Zakona primjenjuju i kod pojedinih pitanja kolektivnih ugovora. Dakle, odredbe ZOO-a, nezaobilazne su nam i kod individualnih i kod kolektivnih radnih odnosa i stoga im se u radnom pravu opravdano pridaje veliki značaj. 


\section{Summary}

\section{EMPLOYMENT CONTRACT AND CIVIL OBLIGATIONS ACT}

In this paper the application of articles of Civil Obligations Act in relation to the employment contract is presented. All the aspects of the employment contract, from formation while the termination of contract in relation to Civil Obligations Act are given. Some instituts like responsibility for damages, deadlines and so on are also analyses and explaned. Tihs paper also presents court practise related to institutes of labor law and Civil Obligation Act.

Keywords: employment contract, Civil Obligations Act, formation employment contract, termination of labour contract, labor law.

\section{Zusammenfassung}

\section{DER ARBEITSVERTRAG IM LICHTE DES GESETZES ÜBER SCHULDVERHÄLTNISSE}

Diese Arbeit setzt sich mit der Anwendung von den Bestimmungen des Gesetzes über Schuldverhältnisse in Punkten, die den Arbeitsvertrag anbelangen, auseinander. In diesem Zusammenhang werden jegliche Fragen des Arbeitsvertrags behandelt: von der Vertragsabschließung, -Änderung bis zum Vertragsende, wobei Rücksicht auf Aspekte, die durch das Gesetz über Schuldverhältnisse geregelt werden, genommen wird. Die Anwendung dieser Bestimmungen sei auch ausschlaggebend für einzelne in Verbindung zum Arbeitsvertrag stehende Rechtinstitute, wie grundlosen Erwerb, Fristensetzung, Haftung für Schaden, der durch die Arbeitsvertragsleistung entstanden ist. Ein tieferer Blick in diese Problematik wird durch die relevante Rechtsprechung des Obersten Gerichtshofs und einigen Landgerichten geboten. Die Praxis bezeugt, dass die Bestimmungen des Gesetzes über Schuldverhältnisse in großem Maße angewendet werden.

Schlüsselwörter: Arbeitsvertrag, Gesetz über Schuldverhältnisse, Vertragsabschließung des Arbeitsvertrags, Vertragsende des Arbeitsvertrags, Arbeitsrecht. 


\section{Riassunto}

\section{IL CONTRATTO DI LAVORO E LA LEGGE SUI RAPPORTI D`OBBLIGAZIONE}

Nel presente contributo si illustra e si analizza l'applicazione delle diposizioni della legge sui rapporti di obbligazione in rapporto alle questioni che si presentano con riferimento al contratto di lavoro. Vengono trattati tutti gli aspetti del contratto di lavoro, partendo dalla conclusione del medesimo, attraverso le sue modifiche e fino alla cessazione di tale contratto e prestando particolare attenzione per le questioni che vengono risolte mediante l'applicazione della legge sui rapporti di obbligazione. Oltre a ciò, l'applicazione di tali norme è rilevante anche con riguardo a singoli istituti giuridici collegati al contratto di lavoro, come nel caso dell'arricchimento senza causa, del calcolo dei termini e della responsabilità per il danno sorto in occasione dell'adempimento delle obbligazioni derivanti dal contratto di lavoro. Rispetto a tutte le questioni che vengono trattate, s'illustra altresì la giurisprudenza con l'intento di interpretare gli orientamenti della Corte Suprema e delle Corti d'appello, come pure al fine di dimostrare che le disposizioni della legge sui rapporti di obbligazione vengono largamente utilizzate nella prassi per la risoluzione di singole questioni connesse al contratto di lavoro.

Parole chiave: contratto di lavoro, legge sui rapporti di obbligazione, conclusione del contratto di lavoro, cessazione del contratto di lavoro, dirtto di lavoro. 